\title{
Synthesis and Evaluation of Pyrrolin-2-one Compounds, a Series of Plasminogen Activator Inhibitor-1 Inhibitors
}

\author{
Hiroshi Miyazaki, ${ }^{* a}$ Tsuyoshi Ogiku, ${ }^{a}$ Hiroshi SAI,${ }^{a}$ Yasunori Moritani,${ }^{a}$ Akio Ohtani, ${ }^{b}$ and \\ Hiroshi OHмIzU ${ }^{a}$ \\ ${ }^{a}$ Medicinal Chemistry Laboratory, Mitsubishi Tanabe Pharma Co., Ltd.; 3-16-89 Kashima, Yodogawa, Osaka 532-8505, \\ Japan: and ${ }^{b}$ Pharmacology Laboratory, Mitsubishi Tanabe Pharma Co., Ltd.; 2-2-50 Kawagishi, Toda, Saitama \\ 335-8505, Japan. Received May 19, 2009; accepted June 16, 2009; published online June 18, 2009
}

A novel series of furan-2-one and pyrrolin-2-one derivatives having PAI-1 (plasminogen activator inhibitor1) inhibitory activity were synthesized and evaluated for their antithrombotic activity in a rat arterial thrombosis model. Among the synthesized compounds, 5f (T-1776Na) was found to have good selectivity for PAI-1 over other enzymes and high antithrombotic activity.

Key words plasminogen activator inhibitor-1; inhibitor; antithrombotic drug; furan-2-one; pyrrolin-2-one

Plasminogen activator inhibitor-1 (PAI-1) is an effective fast-acting inhibitor of both tissue-type plasminogen activator (t-PA) and two-chain urokinase-type plasminogen activator (tcu-PA), and thus plays an important role in regulation of the fibrinolytic system. ${ }^{1)}$ Elevated levels of PAI-1 in plasma have been observed in patients with deep vein thrombosis ${ }^{2-4)}$ and unstable angina. ${ }^{5)}$ Furthermore, a number of animal studies have shown that PAI-1 is responsible for fibrinolytic activity in thrombotic and prethrombotic states. ${ }^{6-8)}$ Thus, inhibition of PAI-1 activity or reduction of its production may shift the balance between thrombogenesis and thrombolysis towards thrombolysis. In fact, it has been reported that an antibody against PAI-1 can enhance clot lysis and decrease thrombus growth in animal models of venous thrombosis ${ }^{9)}$ and arterial thrombosis. ${ }^{10)}$ Therefore, therapeutic inhibition of PAI-1 activity or reduction of its production may be useful for prevention and/or treatment of thrombotic disorders. Indeed, a number of small molecules that inhibit PAI-1 or reduce its production have recently been reported. ${ }^{11-20)}$

High-throughput screening of Mitsubishi Tanabe chemical libraries led to the discovery of 4-methyl-3-phenyl-5-[1pyridin-4-ylmeth- $(E)$-ylidene]-5H-furan-2-one hydrochloride (1a) as a weak PAI-1 inhibitor $\left(\mathrm{IC}_{50}=24 \mu \mathrm{M}\right.$, Fig. 1). To improve the inhibitory activity of $\mathbf{1 a}$ towards PAI-1, we carried out a series of chemical modifications. In this paper, we describe the synthesis, structure-activity relationships (SAR), and antithrombotic activity of a series of furan-2-one and pyrrolin-2-one derivatives.

\section{Chemistry}

The synthetic route of furan-2-one derivatives is shown in Chart 1 . The furan-2-one derivatives $\mathbf{1 a}$ and $\mathbf{1 b}$ were synthesized from 4-methyl-3-phenyl-2,5-dihydrofuran-2-one $7 .^{21}$ Treatment of 7 with lithium diisopropylamide (LDA) followed by 4-pyridinecarboxaldehyde and dehydration after methanesulfonylation of the hydroxyl group afforded the

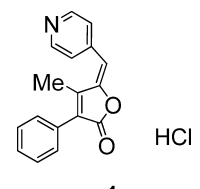

1a products $\mathbf{8 a}$ (as a minor product) and $\mathbf{8 b}$ (as a major product) in which the 5-pyridylmethylidene parts were introduced. Compounds $\mathbf{8 a}$ and $\mathbf{8 b}$ were separated by silica gel chromatography and transformed to their $\mathrm{HCl}$ salts $\mathbf{1 a}$ and $\mathbf{1 b}$, respectively.

4-Methyllactam (pyrrolin-2-one) compounds were synthe-

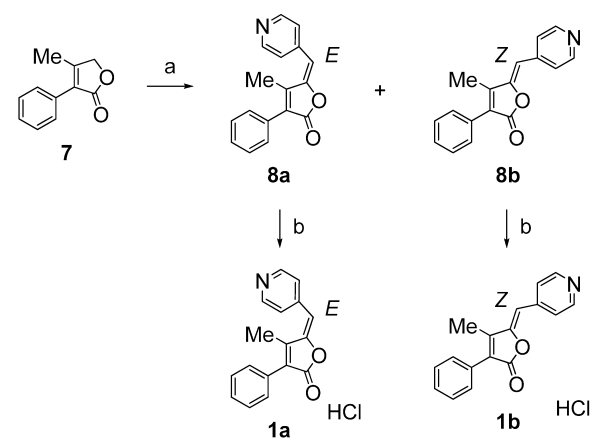

Reagents: (a) i) LDA, 4-pyridinecarboxaldehyde, THF ii) $\mathrm{MsCl}, \mathrm{Et}_{3} \mathrm{~N}$, $\mathrm{CH}_{2} \mathrm{Cl}_{2}$, iii) $\mathrm{DBU}, \mathrm{CH}_{2} \mathrm{Cl}_{2}$; (b) $\mathrm{HCl}, \mathrm{AcOEt} \mathrm{CHCl}_{3}$

Chart 1
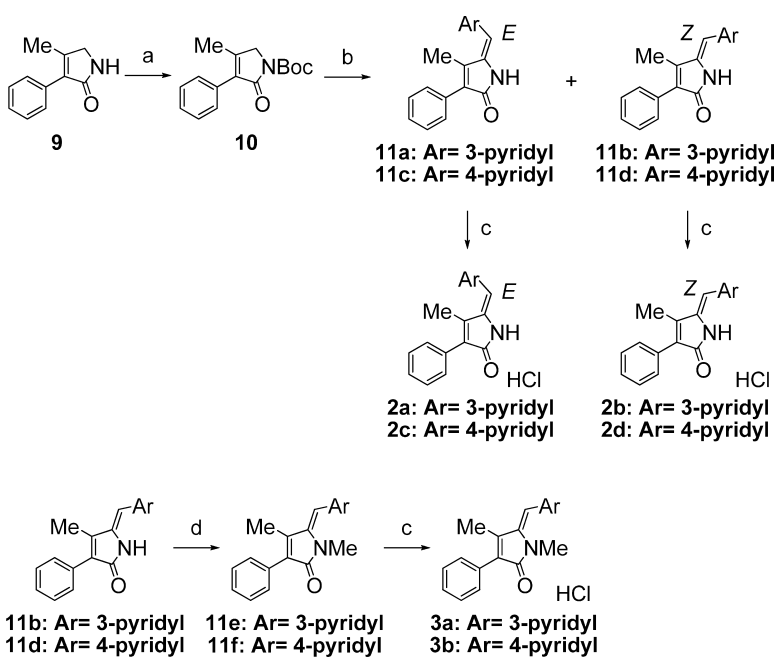

Reagents: (a) $\mathrm{Boc}_{2} \mathrm{O}$, DMAP, $\mathrm{CH}_{2} \mathrm{Cl}_{2}$; (b) i) LiHMDS, THF ii) 3- or-4pyridinecarboxaldehyde, THF; (c) $\mathrm{HCl}, \mathrm{AcOEt}, \mathrm{CHCl}_{3}$; (d) NaH, Mel, DMF 


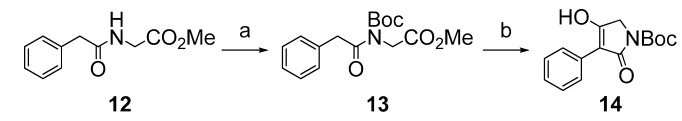

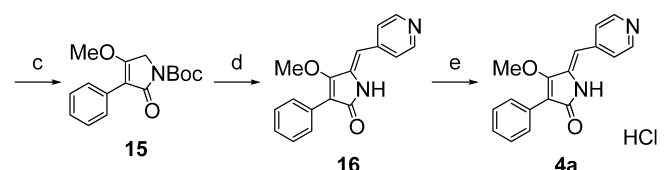<smiles>COc1cccc(C2NC(=O)C(c3ccccc3)C2C(=O)OCc2ccccc2)c1</smiles>

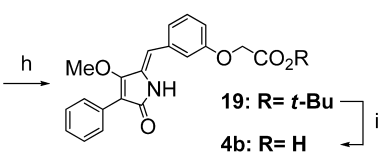

Reagents: (a) Boc ${ }_{2} \mathrm{O}$ DMAP, $\mathrm{CH}_{3} \mathrm{CN}$; (b) $t$-BuOK, DMF; (c) $\mathrm{Me}_{2} \mathrm{SO}_{4}$ $\mathrm{K}_{2} \mathrm{CO}_{3}$, acetone; (d) i) $\mathrm{KHMDS}$, toluene, THF ii) 4-pyridinecarboxaldehyde, THF; (e) HCl, dioxane, THF; (f) i) KHMDS, toluene, THF ii) 3THF; (e) $\mathrm{HCl}$, dioxane, THF; (f) i) $\mathrm{KHMDS}$, toluene, THF ii) 3-
methoxymethoxybenzaldehyde; (g) $\mathrm{HCl}$ aq., THF; (h) $\mathrm{NaH}, \mathrm{BrCH}_{2} \mathrm{CO}_{2} t-$ $\mathrm{Bu}, \mathrm{DMF}$; (i) TFA, $\mathrm{CH}_{2} \mathrm{Cl}_{2}$.

\section{Chart 3}

sized as shown in Chart 2. The acidic $\mathrm{NH}$ proton of $\mathbf{9}^{22)}$ was first protected with tert-butoxycarbonyl (Boc), and then the 5-pyridylmethylidene parts were introduced under basic conditions. These reactions proceeded with good $Z$-selectivity in cases of pyrrolin-2-one as well as furan-2-one, and separation of $E$ and $Z$-products by silica gel chromatography followed by conversion to their $\mathrm{HCl}$ salts gave the 5-pyridylmethylidenepyrrolin-2-one compounds $\mathbf{2 a - d}$. Compounds 11b and 11d were then methylated by $\mathrm{NaH}$ and $\mathrm{MeI}$, and converted to their $\mathrm{HCl}$ salts $\mathbf{3} \mathbf{a}$ and $\mathbf{3} \mathbf{b}$, respectively.

The synthetic route of 4-methoxylactam (pyrrolin-2-one) compounds is shown in Chart 3. Compounds $\mathbf{4 a}$ and $\mathbf{4 b}$ were synthesized from the amide compound 12. After 12 was protected with Boc, the product $\mathbf{1 3}$ was cyclized under basic conditions and transformed into the intermediate 15. Compound $\mathbf{4 a}$ was obtained from $\mathbf{1 5}$ by the same method as $\mathbf{2 d}$ in two steps. In the case of compound $\mathbf{4 b}$, methoxymethyl (MOM)-protected 3-hydroxyphenyl was first introduced and the product 17 was converted to the 3-carboxymethoxyphenyl compound $\mathbf{4 b}$ by a conventional method.

The 4-phenyllactam or 4-heteroaryllactam (pyrrolin-2one) compounds $\mathbf{5 a}-\mathbf{j}$ and $\mathbf{6}$ were synthesized as follows (Chart 4, 5). 3,4-Diphenyl-1,5-dihydropyrrol-2-one 6 was synthesized in a similar manner as the literature. ${ }^{23)} \mathrm{N}-(2$ Oxo-2-phenylethyl)-2-phenylacetamide $\mathbf{2 0}$ was cyclized to give 21 by treatment with acetic anhydride, and cleavage of the $N$-acetyl group of 21 provided 3,4-diphenyl-1,5-dihydropyrrol-2-one 6. After various substituents were introduced into the 5-position of the $N$-acetyl compound 21 or $N$-Boc protected compound $\mathbf{2 2}$, several conventional conversions afforded the 4-phenyllactam compounds $\mathbf{5} \mathbf{a}-\mathbf{h}$.

In the case of 2-furyl at the 4-position of pyrrolin-2-one, $\mathbf{5 i}$ was obtained by introducing a substituent at the 5-position of $\mathbf{2 7}^{24)}$ without $\mathrm{NH}-\mathrm{Boc}$ protection. The thienyl compound $\mathbf{5 j}$ was provided in a similar manner as $\mathbf{5 i}$ from the commercially available $\mathbf{2 8}$ in three steps.

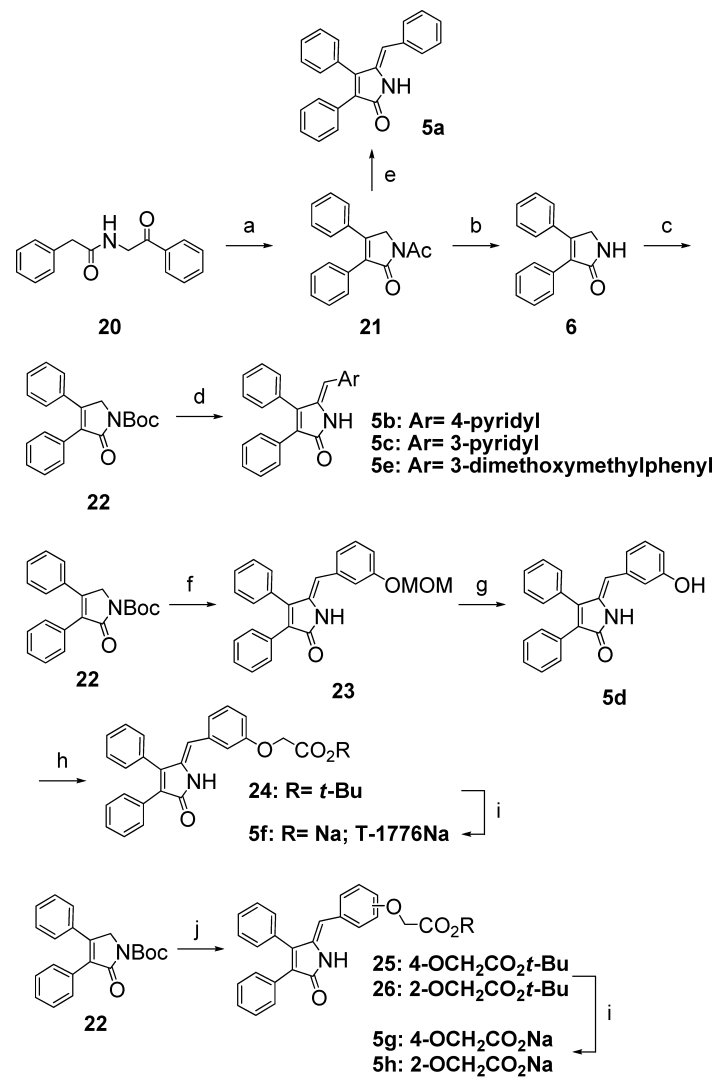

Reagents: (a) $\mathrm{Ac}_{2} \mathrm{O}, \mathrm{Et}_{3} \mathrm{~N}$; (b) $\mathrm{NaOMe}, \mathrm{MeOH}$; (c) $\mathrm{Boc}_{2} \mathrm{O}$, DMAP, $\mathrm{CH}_{3} \mathrm{CN}$; (d) i) $\mathrm{KHMDS}$, toluene, THF ii) 4- or 3-pyridinecarboxaldehyde or 3-dimethoxymethylbenzaldehyde, THF; (e) i) KHMDS, toluene, THF ii) benzaldehyde, THF. (f) 3-methoxymethoxybenzaldehyde, KHMDS, ii) benzaldehyde, THF. (f) 3-methoxymethoxybenzaldehyde, KHMDS,
toluene, THF; (g) $\mathrm{HCl}$ aq., THF; (h) $\mathrm{BrCH}_{2} \mathrm{CO}_{2} t$ - $\mathrm{Bu}, \mathrm{NaH}$, DMF; (i) i) TFA, $\mathrm{CH}_{2} \mathrm{Cl}_{2}$ ii) $\mathrm{NaOH}$ aq., $\mathrm{MeOH}$; (j) $\mathrm{OHCC}_{6} \mathrm{H}_{4}\left(4-\right.$ or $2-\mathrm{OCH}_{2} \mathrm{CO}_{2} t-$ $\mathrm{Bu}), \mathrm{KHMDS}$, toluene, THF

Chart 4

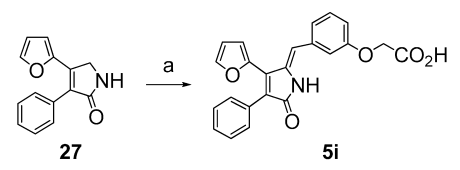<smiles>NC(=O)c1ccc(-c2cccc(C(=O)NCC(=O)OCc3ccccc3)c2)s1</smiles><smiles></smiles>

Reagents: (a) $\mathrm{OHCC}_{6} \mathrm{H}_{4}\left(3-\mathrm{OCH}_{2} \mathrm{CO}_{2} t-\mathrm{Bu}\right), \mathrm{NaOH}, \mathrm{MeOH}, \mathrm{H}_{2} \mathrm{O}$; (b) phenylacetic acid, $\mathrm{CDI}, \mathrm{Et}_{3} \mathrm{~N}, \mathrm{CH}_{2} \mathrm{Cl}_{2}$; (c) $\mathrm{NaOMe}, \mathrm{EtOH}$.

Chart 5

\section{Biological Results and Discussion}

The inhibitory activity of furan-2-one and pyrrolin-2-one derivatives for human PAI-1 is summarized in Tables 1 and 2 . The Z-isomer $\mathbf{1 b}$ showed better PAI-1 inhibitory activity than the $E$-isomer 1a. However, these furan-2-one compounds $(\mathbf{1 a}, \mathbf{b})$ were biologically unstable. This instability was believed to be due to their $\alpha, \beta$-unsaturated lactone ring. As such, 1a and $\mathbf{1 b}$ were considered inappropriate for inhibition of thrombus formation in vivo. Thus, we tried to transform 
the lactone ring into a more stable scaffold. The pyrrolin-2one compounds $\mathbf{2 a}-\mathbf{d}$, having a 3 or 4 -pyridine ring at the 5 position, were first evaluated. The 3-pyridine compound $\mathbf{2 b}$ showed strong inhibitory activity for human PAI-1 $\left(\mathrm{IC}_{50}=9.8 \mu \mathrm{M}\right)$. However, in case of the pyrrolin-2-ones, the inhibitory activity of the $E$-isomer $\mathbf{2 a}$ and that of the 4-pyridine compounds $\mathbf{2 c}$ and $\mathbf{2 d}$ was low. Furthermore, the $\mathrm{N}$ methylated compounds $\mathbf{3} \mathbf{a}$ and $\mathbf{3} \mathbf{b}$ had no PAI-1 inhibitory activity. This led us to examine the SAR of pyrrolin-2-one derivatives with no subsitituent at the 1-position.

Our search for more attractive templates focused on substituents at the 4-position of the pyrrolin-2-one ring (Table 2). In case of a methoxy group, compounds $\mathbf{4 a}$ and $\mathbf{4 b}$ exhibited no inhibitory activity. Next, a phenyl group was introduced. The phenylmethylidene compound $\mathbf{5 a}$ and the 4pyridylmethylidene compounds $\mathbf{5 b}$ and $\mathbf{6}$, having no substituent at the 5-position, did not inhibit human PAI-1. However, 3-pyridylmethylidene 5c showed potent inhibitory activity for human PAI-1 $\left(\mathrm{IC}_{50}=12.6 \mu \mathrm{M}\right)$. These findings suggest that hydrophilic groups at the meta-position of the aro-

Table 1. Inhibitory Effect of Furan-2-one and Pyrrolin-2-one Derivatives against Human PAI-1 Activity ${ }^{a}$
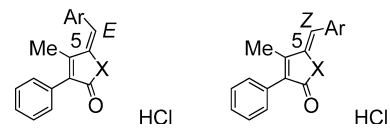

\begin{tabular}{|c|c|c|c|c|}
\hline Compound & $\begin{array}{l}\text { Configuration at } \\
\text { C-5 position }\end{array}$ & $\mathrm{X}$ & $\mathrm{Ar}$ & $\begin{array}{l}\left.\text { Inhibitory activity }^{a}\right) \\
\qquad \operatorname{IC}_{50}(\mu \mathrm{M})\end{array}$ \\
\hline 1a & $E$ & $\mathrm{O}$ & 4-Pyridyl & $24 \mu \mathrm{M}$ \\
\hline 1b & $Z$ & $\mathrm{O}$ & 4-Pyridyl & $5.6 \mu \mathrm{M}$ \\
\hline $2 \mathbf{a}$ & $E$ & $\mathrm{NH}$ & 3-Pyridyl & $7 \%$ inhibition at $30 \mu \mathrm{M}$ \\
\hline $2 \mathbf{b}$ & $Z$ & $\mathrm{NH}$ & 3-Pyridyl & $9.8 \mu \mathrm{M}$ \\
\hline $2 c$ & $E$ & $\mathrm{NH}$ & 4-Pyridyl & $5 \%$ inhibition at $30 \mu \mathrm{M}$ \\
\hline $2 d$ & $Z$ & $\mathrm{NH}$ & 4-Pyridyl & $24 \%$ inhibition at $10 \mu \mathrm{M}$ \\
\hline 3a & $Z$ & $\mathrm{NMe}$ & 3-Pyridyl & $2 \%$ inhibition at $30 \mu \mathrm{M}$ \\
\hline $\mathbf{3 b}$ & $Z$ & $\mathrm{NMe}$ & 4-Pyridyl & $4 \%$ inhibition at $30 \mu \mathrm{M}$ \\
\hline
\end{tabular}

a) See Experimental. matic ring, which extends from the 5-position, are favorable for PAI-1 inhibitory activity. Other hydrophilic substituents, such as alcohol (5d), dimethylacetal (5e) and carboxylic acid (5f), were also examined. Compound 5d did not inhibit human PAI-1, while compound 5e showed a moderate inhibitory activity $\left(\mathrm{IC}_{50}=7.9 \mu \mathrm{M}\right)$. Particularly, compound $\mathbf{5 f}$, having a carboxylic acid group, was found to have potent PAI-1 inhibitory activity $\left(\mathrm{IC}_{50}=9.6 \mu \mathrm{M}\right)$.

Next we focused our efforts on optimizing compound $\mathbf{5 f}$, having a phenoxy acetic acid group. However, compounds $\mathbf{5 g}$ and $\mathbf{5 h}$, having a 4- or 2-phenoxy acetic acid moiety, and compounds $\mathbf{5 i}$ and $\mathbf{5 j}$, having a furan or thiophene at the 4position of pyrrolin-2-one ring, exhibited less potent inhibitory activity for human PAI-1 than compound $\mathbf{5 f}$.

In order to select the best compound, the synthesized pyrrolin-2-one compounds were evaluated for their antithrombotic activity in rat arterial thrombosis model. Compounds $\mathbf{2 b}, \mathbf{5} \mathbf{c}$, and $\mathbf{5 e}$ could not be intravenously infused to rats due to their poor solubility. They were thus considered not to have the desired features for antithrombotic drug. On the other hand, compound $\mathbf{5 f}$, possessing a carboxylic acid group at the 5-position of the pyrrolin-2-one ring, had good solubility and was found to decrease thrombus weight at a dose of $0.5 \mu \mathrm{g} / \mathrm{kg} / \mathrm{min}$. Finally, we evaluated the selectivity of compound $\mathbf{5 f}$ for rat PAI-1. Compound $\mathbf{5 f}$ inhibited rat PAI-1 with an $\mathrm{IC}_{50}$ value of $10.3 \mu \mathrm{M}$, which is almost equal to its inhibition of human PAI-1. Compound $\mathbf{5 f}$ showed no inhibitory effect against the serine proteases thrombin, plasmin, and trypsin, and the serpins antithrombin III, antiplasmin, and antitrypsin at $30 \mu \mathrm{M}$. It shows the antithrombotic activity of $\mathbf{5 f}$ is thought to be based on its PAI-1 inhibition.

\section{Conclusion}

In this study, we examined the structure-activity relationships of a series furan-2-one derivatives. Initial modification led to identification of the pyrrolin-2-one template as a promising scaffold. Optimization of the pyrrolin-2-one derivatives resulted in identification of $\mathbf{5 f}(\mathrm{T}-1776 \mathrm{Na})$ as a potent PAI-1

Table 2. Inhibitory Effect of Pyrrolin-2-one Derivatives against Human PAI-1 Activity ${ }^{a)}$ and Their Antithrombotic Activity ${ }^{b}$

\begin{tabular}{|c|c|c|c|c|}
\hline Compound & $\mathrm{R}$ & $\mathrm{Ar}$ & $\begin{array}{l}\text { Inhibitory activity }{ }^{a)} \\
\operatorname{IC}_{50}(\mu \mathrm{M})\end{array}$ & $\begin{array}{c}\% \text { decrease in } \\
\text { thrombus weight }{ }^{b)}\end{array}$ \\
\hline $2 \mathbf{b}$ & $\mathrm{Me}$ & 3-Pyridyl & $9.8 \mu \mathrm{M}$ & $\mathrm{nt}^{c)}$ \\
\hline $4 a$ & $\mathrm{OMe}$ & 4-Pyridyl $(\mathrm{HCl})$ & No effect at $30 \mu \mathrm{M}$ & \\
\hline $4 b$ & $\mathrm{OMe}$ & 3-Carboxymehoxyphenyl & No effect at $30 \mu \mathrm{M}$ & \\
\hline $5 a$ & $\mathrm{Ph}$ & $\mathrm{Ph}$ & No effect at $15 \mu \mathrm{M}$ & \\
\hline $5 \mathbf{b}$ & $\mathrm{Ph}$ & 4-Pyridyl & No effect at $30 \mu \mathrm{M}$ & \\
\hline $5 c$ & $\mathrm{Ph}$ & 3-Pyridyl & $12.6 \mu \mathrm{M}$ & $\mathrm{nt}^{c)}$ \\
\hline 6 & - & - & No effect at $15 \mu \mathrm{M}$ & \\
\hline 5d & $\mathrm{Ph}$ & 3-Hydroxyphenyl & No effect at $30 \mu \mathrm{M}$ & \\
\hline $5 e$ & $\mathrm{Ph}$ & 3-Dimethoxymethylphenyl & $7.9 \mu \mathrm{M}$ & $\mathrm{nt}^{c)}$ \\
\hline $5 f$ & $\mathrm{Ph}$ & 3-Carboxymehoxyphenyl (Na salt) & $9.6 \mu \mathrm{M}$ & $43.4 \%$ \\
\hline $5 \mathrm{~g}$ & $\mathrm{Ph}$ & 4-Carboxymehoxyphenyl (Na salt) & No effect at $30 \mu \mathrm{M}$ & \\
\hline $5 \mathrm{~h}$ & $\mathrm{Ph}$ & 2-Carboxymehoxyphenyl (Na salt) & $32 \%$ inhibition at $30 \mu \mathrm{M}$ & \\
\hline $5 \mathbf{i}$ & 2-Furyl & 3-Carboxymehoxyphenyl & $30 \%$ inhibition at $30 \mu \mathrm{M}$ & \\
\hline $5 \mathbf{j}$ & 2-Thienyl & 3-Carboxymehoxyphenyl & $27 \%$ inhibition at $30 \mu \mathrm{M}$ & \\
\hline
\end{tabular}


inhibitor. Compound $\mathbf{5 f}$ was selected for further biological evaluation and was found to possess good antithrombotic activity in rat model. Compound $\mathbf{5 f}$ was also found to have good selectivity for PAI-1 over serine proteases and serpins. These findings indicate that pyrrolin-2-one derivatives are potential candidates for antithrombotic drugs. Accordingly, compound $\mathbf{5 f}$ has been selected as lead compound and further research on its antithrombotic effects are on going.

\section{Experimental}

Melting points were measured using a Büchi 535 capillary melting point apparatus and are uncorrected. IR spectra were recorded on a PerkinElmer Spectrum One FT-IR spectrometer. ${ }^{1} \mathrm{H}-\mathrm{NMR}$ spectra were recorded on a Bruker AC-200 spectrometer (200 MHz) or on a Bruker AVANCE $400 \mathrm{spec}-$ trometer $(400 \mathrm{MHz})$ with $\mathrm{Me}_{4} \mathrm{Si}$ as internal standard. Mass spectra were obtained on a ThermoFisher FINNIGAN LXQ or Q-TOF Ultima API mass spectrometer. Elemental analyses were obtained on a PerkinElmer $2400 \mathrm{II}$ (C, H, N) and Dionex DX-320 (S).

4-Methyl-3-phenyl-5-[1-pyridin-4-ylmeth-(E)-ylidene]-5H-furan-2one Hydrochloride (1a); 4-Methyl-3-phenyl-5-[1-pyridin-4-ylmeth-(Z)ylidene]-5 $\boldsymbol{H}$-furan-2-one Hydrochloride (1b) $1.6 \mathrm{M} n$-BuLi in hexane $(5.4 \mathrm{ml}, 8.6 \mathrm{mmol})$ was slowly added to a solution of diisopropylamine $(1.2 \mathrm{ml}, 8.6 \mathrm{mmol})$ in tetrahydrofuran (THF) $(15 \mathrm{ml})$ at $-78^{\circ} \mathrm{C}$. The solution was stirred for $30 \mathrm{~min}$ at the same temperature and 4-methyl-3-phenyl-2,5dihydrofuran-2-one $7^{21)}(1.0 \mathrm{~g}, 5.7 \mathrm{mmol})$ in THF $(15 \mathrm{ml})$ was added dropwise to the solution. The mixture was stirred for $30 \mathrm{~min}$ at $-78^{\circ} \mathrm{C}$ and 4 pyridinecarboxaldehyde $(0.92 \mathrm{~g}, 8.6 \mathrm{mmol})$ in THF $(5 \mathrm{ml})$ was added dropwise to the mixture. After the addition, the mixture was further stirred for $1 \mathrm{~h}$ at $-78^{\circ} \mathrm{C}$. Water and ethyl acetate were added to the mixture and the organic layer was separated. The organic layer was then dried and concentrated in vacuo. The resulting residue was dissolved in $\mathrm{CH}_{2} \mathrm{Cl}_{2}(20 \mathrm{ml})$, and triethylamine $(1.2 \mathrm{ml}, 8.6 \mathrm{mmol})$ and methanesulfonyl chloride $(0.67 \mathrm{ml}, 8.6 \mathrm{mmol})$ were added to the solution at $0{ }^{\circ} \mathrm{C}$. The mixture was stirred for $30 \mathrm{~min}$ at $0^{\circ} \mathrm{C}$ and 1,8 -diazabicyclo[5,4,0]undec-7-ene (DBU) $(1.3 \mathrm{ml}, 8.6 \mathrm{mmol})$ was added. After the addition, the reaction mixture was further stirred for $30 \mathrm{~min}$ at $0{ }^{\circ} \mathrm{C}$. Water and $\mathrm{CHCl}_{3}$ were then added to the mixture and the organic layer was separated. The organic layer was dried and concentrated in vacuo. The residue was chromatographed on silica gel to give $75 \mathrm{mg}(5 \%)$ of 4 methyl-3-phenyl-5-[1-pyridin-4-ylmeth-( $E$ )-ylidene]-5H-furan-2-one $\quad(\mathbf{8 a})$ and $1.16 \mathrm{~g}(77 \%)$ of 4-methyl-3-phenyl-5-[1-pyridin-4-ylmeth-(Z)-ylidene]$5 H$-furan-2-one $(\mathbf{8 b})$ as a solid. $\mathrm{mp} 127-128^{\circ} \mathrm{C}(\mathbf{8 a}), 189-190^{\circ} \mathrm{C}(\mathbf{8 b})$.

To a 8 a $(200 \mathrm{mg}, 0.76 \mathrm{mmol})$ solution in $\mathrm{CHCl}_{3}(10 \mathrm{ml})$ was added $4 \mathrm{~N}$ $\mathrm{HCl}$ in ethyl acetate $(0.19 \mathrm{ml})$ and the mixture was stirred for $10 \mathrm{~min}$. The reaction mixture was then concentrated in vacuo. The resulting residue was triturated with diethyl ether and filtrated to afford 1a (212 mg, 93\%) as a solid. mp $>230{ }^{\circ} \mathrm{C}$. ${ }^{1} \mathrm{H}-\mathrm{NMR}\left(400 \mathrm{MHz}, \mathrm{DMSO}-d_{6}\right) \delta: 2.03(3 \mathrm{H}, \mathrm{s}), 7.21$ $(1 \mathrm{H}, \mathrm{s}), 7.45-7.58(5 \mathrm{H}, \mathrm{m}), 8.05(2 \mathrm{H}, \mathrm{d}, J=6.4 \mathrm{~Hz}), 8.89(2 \mathrm{H}, \mathrm{d}$, $J=6.4 \mathrm{~Hz}$ ). IR (ATR) $\mathrm{cm}^{-1}: 3045,2948,2382,2117,2011,1754,1652$, 1627, 1598, 1494, 1178, 1058, 981, 789, 750, 696, 536, 481. MS (APCI): $264[\mathrm{M}+\mathrm{H}]^{+}$. HR-MS-ESI Calcd for $\mathrm{C}_{17} \mathrm{H}_{14} \mathrm{NO}_{2}\left([\mathrm{M}+\mathrm{H}]^{+}\right): 264.1025$. Found: 264.1024

$\mathbf{1 b}$, prepared from $\mathbf{8 b}$ as described in the synthesis of $\mathbf{1 a}$, was obtained as a solid. Yield $94 \%$. mp $279-280{ }^{\circ} \mathrm{C}$ (dec.). ${ }^{1} \mathrm{H}-\mathrm{NMR}\left(400 \mathrm{MHz}, \mathrm{DMSO}-d_{6}\right)$ $\delta: 2.41(3 \mathrm{H}, \mathrm{s}), 6.90(1 \mathrm{H}, \mathrm{s}), 7.45-7.70(5 \mathrm{H}, \mathrm{m}), 8.22(2 \mathrm{H}, \mathrm{d}, J=6.7 \mathrm{~Hz})$, $8.88(2 \mathrm{H}, \mathrm{d}, J=6.7 \mathrm{~Hz})$. IR (ATR) $\mathrm{cm}^{-1}: 3059,2969,1772,1651,1629$, $1584,1496,1478,1445,1186,1153,953,871,797,786,692,546$. MS (APCI): $264[\mathrm{M}+\mathrm{H}]^{+}$. HR-MS-ESI Calcd for $\mathrm{C}_{17} \mathrm{H}_{14} \mathrm{NO}_{2}\left([\mathrm{M}+\mathrm{H}]^{+}\right)$: 264.1025. Found: 264.1022.

4-Methyl-2-oxo-3-phenyl-2,5-dihydropyrrole-1-carboxylic Acid tertButyl Ester (10) To a solution of 4-methyl-3-phenyl-1,5-dihydropyrrol-2one $9^{22)}(5.1 \mathrm{~g}, 29.4 \mathrm{mmol})$ in $\mathrm{CH}_{2} \mathrm{Cl}_{2}(50 \mathrm{ml})$ were added $(\mathrm{Boc})_{2} \mathrm{O}(9.6 \mathrm{~g}$, $44.2 \mathrm{mmol})$ and $N, N$-dimethyl-4-aminopyridine $(72 \mathrm{mg}, 0.59 \mathrm{mmol})$ and the mixture was stirred at $40^{\circ} \mathrm{C}$ for $30 \mathrm{~min}$. After the reaction mixture was concentrated in vacuo, the resulting residue was chromatographed on silica gel to give $5.8 \mathrm{~g} \mathrm{(72 \% )} \mathrm{of} \mathrm{10.} \mathrm{mp} 127-128^{\circ} \mathrm{C} .{ }^{1} \mathrm{H}-\mathrm{NMR}\left(400 \mathrm{MHz}\right.$, DMSO- $\left.d_{6}\right)$ $\delta: 1.49(9 \mathrm{H}, \mathrm{s}), 2.11(3 \mathrm{H}, \mathrm{s}), 4.34(2 \mathrm{H}, \mathrm{s}), 7.34-7.40(3 \mathrm{H}, \mathrm{m}), 7.41-7.47$ (2H, m). IR (ATR) $\mathrm{cm}^{-1}: 2980,1748,1362,1302,1161,1093,695 . \mathrm{MS}$ (APCI): $274[\mathrm{M}+\mathrm{H}]^{+}$. Anal. Calcd for $\mathrm{C}_{16} \mathrm{H}_{19} \mathrm{NO}_{3}: \mathrm{C}, 70.31 ; \mathrm{H}, 7.01 ; \mathrm{N}$, 5.12. Found: C, 70.28; H, 7.05; N, 5.09

4-Methyl-3-phenyl-5-[1-pyridin-3-ylmeth-(E)-ylidene]-1,5-dihydropyrrol-2-one Hydrochloride (2a); 4-Methyl-3-phenyl-5-[1-pyridin-3ylmeth-(Z)-ylidene]-1,5-dihydropyrrol-2-one Hydrochloride (2b) $1 \mathrm{M}$
Lithium bis(trimethylsilyl)amide in THF $(3.5 \mathrm{ml}, 3.5 \mathrm{mmol})$ was slowly added to a solution of $\mathbf{1 0}(800 \mathrm{mg}, 2.93 \mathrm{mmol})$ in THF $(12 \mathrm{ml})$ at $-78^{\circ} \mathrm{C}$. The mixture was stirred for $30 \mathrm{~min}$ at the same temperature and 4pyridinecarboxaldehyde $(380 \mathrm{mg}, 3.5 \mathrm{mmol})$ in THF $(5 \mathrm{ml})$ was added dropwise. After the addition, the mixture was further stirred for $30 \mathrm{~min}$ at $-78^{\circ} \mathrm{C}$ and for $16 \mathrm{~h}$ at room temperature. Water and ethyl acetate were added to the mixture and the organic layer was separated. The organic layer was dried and concentrated in vacuo. The resulting residue was chromatographed on silica gel to give $80 \mathrm{mg}(10 \%)$ of 4-methyl-3-phenyl-5-[1pyridin-3-ylmeth-(E)-ylidene]-1,5-dihydropyrrol-2-one (11a) and $570 \mathrm{mg}$ (74\%) of 4-methyl-3-phenyl-5-[1-pyridin-3-ylmeth-(Z)-ylidene]-1,5-dihydropyrrol-2-one hydrochloride (11b) as a solid. mp $180-182^{\circ} \mathrm{C}(\mathbf{1 1 a})$, $230-231^{\circ} \mathrm{C}(\mathbf{1 1 b})$

To a solution of $11 \mathbf{b}(150 \mathrm{mg}, 0.57 \mathrm{mmol})$ in $\mathrm{CHCl}_{3}(10 \mathrm{ml})$ was added $4 \mathrm{~N}$ $\mathrm{HCl}$ in ethyl acetate $(0.16 \mathrm{ml})$ and the mixture was stirred for $10 \mathrm{~min}$. The reaction mixture was concentrated in vacuo, and the resulting residue was triturated with diethyl ether and filtrated to afford $\mathbf{2 b}(162 \mathrm{mg}, 95 \%)$ as a solid. mp $311-314{ }^{\circ} \mathrm{C}\left(\mathrm{dec}\right.$.). ${ }^{1} \mathrm{H}-\mathrm{NMR}\left(400 \mathrm{MHz}, \mathrm{DMSO}-d_{6}\right) \delta: 2.30(3 \mathrm{H}$, s), $6.54(1 \mathrm{H}, \mathrm{s}), 7.37-7.57(5 \mathrm{H}, \mathrm{m}) 7.95(1 \mathrm{H}, \mathrm{dd}, J=8.2,5.5 \mathrm{~Hz}), 8.57(1 \mathrm{H}$, d, $J=8.5 \mathrm{~Hz}), 8.73(1 \mathrm{H}, \mathrm{d}, J=5.5 \mathrm{~Hz}), 9.00(1 \mathrm{H}, \mathrm{d}, J=1.8 \mathrm{~Hz}), 10.64(1 \mathrm{H}, \mathrm{s})$. IR (ATR) $\mathrm{cm}^{-1}: 3075,2698,1683,1640,1544,1387,1216,789,671,435$. MS (APCI): $263[\mathrm{M}+\mathrm{H}]^{+}$. HR-MS-ESI Calcd for $\mathrm{C}_{17} \mathrm{H}_{15} \mathrm{~N}_{2} \mathrm{O}\left([\mathrm{M}+\mathrm{H}]^{+}\right)$: 263.1184. Found: 263.1175 .

2a, prepared from 11a as described in the synthesis of $\mathbf{2} \mathbf{b}$, was obtained as a solid. Yield $81 \%$. mp $302-304{ }^{\circ} \mathrm{C}$ (dec.). ${ }^{1} \mathrm{H}-\mathrm{NMR}$ ( $400 \mathrm{MHz}$, DMSO- $d_{6}$ ) $\delta: 1.84(3 \mathrm{H}, \mathrm{s}), 6.60(1 \mathrm{H}, \mathrm{s}), 7.35-7.60(5 \mathrm{H}, \mathrm{m}) 7.88(1 \mathrm{H}, \mathrm{dd}, J=8.0$, $5.5 \mathrm{~Hz}), 8.43(1 \mathrm{H}, \mathrm{d}, J=8.0 \mathrm{~Hz}), 8.76(1 \mathrm{H}, \mathrm{d}, J=5.5 \mathrm{~Hz}), 8.94(1 \mathrm{H}, \mathrm{s}), 10.46$ $(1 \mathrm{H}, \mathrm{s})$. IR (ATR) $\mathrm{cm}^{-1}: 3150,2479,1687,1638,1205,832,598 . \mathrm{MS}$ (APCI): $263[\mathrm{M}+\mathrm{H}]^{+}$. HR-MS-ESI Calcd for $\mathrm{C}_{17} \mathrm{H}_{15} \mathrm{~N}_{2} \mathrm{O}\left([\mathrm{M}+\mathrm{H}]^{+}\right)$: 263.1184. Found: 263.1180 .

4-Methyl-3-phenyl-5-[1-pyridin-4-ylmeth-(E)-ylidene]-1,5-dihydropyrrol-2-one Hydrochloride (2c); 4-Methyl-3-phenyl-5-[1-pyridin-4-ylmeth-(Z)-ylidene]-1,5-dihydropyrrol-2-one Hydrochloride (2d) 2c and 2d, prepared from 10 and 4-pyridinecarboxaldehyde as described in the synthesis of $\mathbf{2 a}$ and $\mathbf{2 b}$, were obtained as a solid. $2 \mathbf{c}$ yield $6 \%$. mp $331-335^{\circ} \mathrm{C}$ (dec.). ${ }^{1} \mathrm{H}-\mathrm{NMR}\left(400 \mathrm{MHz}, \mathrm{DMSO}-d_{6}\right) \delta: 1.96(3 \mathrm{H}, \mathrm{s}), 6.64(1 \mathrm{H}, \mathrm{s}), 7.38$ $7.57(5 \mathrm{H}, \mathrm{m}) 8.01(2 \mathrm{H}, \mathrm{d}, J=6.6 \mathrm{~Hz}), 8.80(2 \mathrm{H}, \mathrm{d}, J=6.6 \mathrm{~Hz}), 10.59(1 \mathrm{H}, \mathrm{s})$. IR (ATR) $\mathrm{cm}^{-1}: 3039,1697,1598,1493,1196,1136,856,697$. MS (APCI): $263[\mathrm{M}+\mathrm{H}]^{+}$. HR-MS-ESI Calcd for $\mathrm{C}_{17} \mathrm{H}_{15} \mathrm{~N}_{2} \mathrm{O}\left([\mathrm{M}+\mathrm{H}]^{+}\right)$: 263.1184 . Found: 263.1173. 2d yield 55\%. mp $322-325^{\circ} \mathrm{C}$ (dec.). ${ }^{1} \mathrm{H}-\mathrm{NMR}$ $\left(400 \mathrm{MHz}, \mathrm{DMSO}-d_{6}\right) \delta: 2.31(3 \mathrm{H}, \mathrm{s}), 6.58(1 \mathrm{H}, \mathrm{s}), 7.40-7.58(5 \mathrm{H}, \mathrm{m})$ $8.09(2 \mathrm{H}, \mathrm{d}, J=6.8 \mathrm{~Hz}), 8.81(2 \mathrm{H}, \mathrm{d}, J=6.8 \mathrm{~Hz}), 10.82(1 \mathrm{H}, \mathrm{s})$. IR (ATR) $\mathrm{cm}^{-1}: 3050,2734,1698,1617,1597,1205,868,802,547 . \mathrm{MS}$ (APCI): 263 $[\mathrm{M}+\mathrm{H}]^{+}$. HR-MS-ESI Calcd for $\mathrm{C}_{17} \mathrm{H}_{15} \mathrm{~N}_{2} \mathrm{O}\left([\mathrm{M}+\mathrm{H}]^{+}\right): 263.1184$.

1,4-Dimethyl-3-phenyl-5-[1-pyridin-3-ylmeth-( $Z$ )-ylidene]-1,5-dihydropyrrol-2-one Hydrochloride (3a) $60 \%$ Sodium hydride in oil $(25 \mathrm{mg}$, $0.63 \mathrm{mmol})$ was slowly added to a solution of $11 \mathrm{~b}(150 \mathrm{mg}, 0.57 \mathrm{mmol})$ in DMF $(3 \mathrm{ml})$. The mixture was stirred for $1 \mathrm{~h}$ at room temperature and methyl iodide $(0.04 \mathrm{ml}, 0.63 \mathrm{mmol})$ was added. After the addition, the mixture was further stirred for $1.5 \mathrm{~h}$ at room temperature. Water and ethyl acetate were added to the mixture and the organic layer was separated. The organic layer was washed with water, dried and concentrated in vacuo. The resulting residue was chromatographed on silica gel to give $100 \mathrm{mg}(63 \%)$ of 1,4-dimethyl-3-phenyl-5-[1-pyridin-3-ylmeth-(Z)-ylidene]-1,5-dihydropyrrol-2one (11e) as a solid. mp $129-130^{\circ} \mathrm{C}$.

To a solution of 11e $(90 \mathrm{mg}, 0.33 \mathrm{mmol})$ in $\mathrm{CHCl}_{3}(10 \mathrm{ml})$ was added $4 \mathrm{~N}$ $\mathrm{HCl}$ in ethyl acetate $(0.09 \mathrm{ml})$ and the mixture was stirred for $10 \mathrm{~min}$. The reaction mixture was then concentrated in vacuo. The resulting residue was triturated with diethyl ether and filtrated to afford 3a $(97 \mathrm{mg}, 95 \%)$ as a solid. mp $213-215^{\circ} \mathrm{C} .{ }^{1} \mathrm{H}-\mathrm{NMR}\left(400 \mathrm{MHz}, \mathrm{DMSO}-d_{6}\right) \delta: 2.30(3 \mathrm{H}, \mathrm{s})$, $2.84(3 \mathrm{H}, \mathrm{s}), 6.68(1 \mathrm{H}, \mathrm{s}), 7.37-7.55(5 \mathrm{H}, \mathrm{m}) 7.87(1 \mathrm{H}, \mathrm{dd}, J=8.0,5.6 \mathrm{~Hz})$, $8.34(1 \mathrm{H}, \mathrm{d}, J=8.0 \mathrm{~Hz}), 8.75(1 \mathrm{H}, \mathrm{d}, J=4.6 \mathrm{~Hz}), 8.90(1 \mathrm{H}, \mathrm{d}, J=1.5 \mathrm{~Hz}) . \mathrm{IR}$ (ATR) $\mathrm{cm}^{-1}: 3415,2515,1683,1633,1554,1438,788,682,547 . \mathrm{MS}$ (APCI): $277[\mathrm{M}+\mathrm{H}]^{+}$. HR-MS-ESI Calcd for $\mathrm{C}_{18} \mathrm{H}_{17} \mathrm{~N}_{2} \mathrm{O}\left([\mathrm{M}+\mathrm{H}]^{+}\right)$: 277.1341. Found: 277.1330

1,4-Dimethyl-3-phenyl-5-[1-pyridin-4-ylmeth-(Z)-ylidene]-1,5-dihydropyrrol-2-one Hydrochloride (3b) This compound, prepared from 11d as described in the synthesis of $\mathbf{3 a}$, was obtained as a solid. Yield $65 \%$. mp $239-241{ }^{\circ} \mathrm{C} .{ }^{1} \mathrm{H}-\mathrm{NMR}\left(400 \mathrm{MHz}, \mathrm{DMSO}-d_{6}\right) \delta: 2.31(3 \mathrm{H}, \mathrm{s}), 2.90(3 \mathrm{H}, \mathrm{s})$, $6.74(1 \mathrm{H}, \mathrm{s}), 7.40-7.56(5 \mathrm{H}, \mathrm{m}) 7.94(2 \mathrm{H}, \mathrm{d}, J=6.5 \mathrm{~Hz}), 8.82(2 \mathrm{H}, \mathrm{d}$, $J=6.5 \mathrm{~Hz}$ ). IR (ATR) $\mathrm{cm}^{-1}: 3499,3374,2615,2073,1689,1621,1606$, $1505,1385,1242,856,632,547 . \mathrm{MS}$ (APCI): $277[\mathrm{M}+\mathrm{H}]^{+}$. HR-MS-ESI Calcd for $\mathrm{C}_{18} \mathrm{H}_{17} \mathrm{~N}_{2} \mathrm{O}\left([\mathrm{M}+\mathrm{H}]^{+}\right)$: 277.1341. Found: 277.1330.

tert-Butoxycarbonylphenylacetylaminoacetic Acid Methyl Ester (13) 
To a solution of phenylacetylaminoacetic acid methyl ester 12 (500 mg, $2.41 \mathrm{mmol})$ in acetonitrile $(20 \mathrm{ml})$ were added $(\mathrm{Boc})_{2} \mathrm{O}(630 \mathrm{mg}, 2.89 \mathrm{mmol})$ and $N, N$-dimethyl-4-aminopyridine $(15 \mathrm{mg}, 0.12 \mathrm{mmol})$ at $0{ }^{\circ} \mathrm{C}$ and the mixture was stirred at room temperature for $2 \mathrm{~h}$. After the reaction mixture was concentrated in vacuo, water and ethyl acetate were added to the residue. The organic layer was separated, washed with brine, dried and concentrated in vacuo. The resulting residue was chromatographed on silica gel to give $405 \mathrm{mg}(55 \%)$ of 13 as an oil. ${ }^{1} \mathrm{H}-\mathrm{NMR}\left(200 \mathrm{MHz}, \mathrm{CDCl}_{3}\right) \delta: 1.48(9 \mathrm{H}, \mathrm{s})$, $3.73(3 \mathrm{H}, \mathrm{s}), 4.30(2 \mathrm{H}, \mathrm{s}), 4.47(2 \mathrm{H}, \mathrm{s}), 7.15-7.40(5 \mathrm{H}, \mathrm{m})$. MS (SIMS): $308[\mathrm{M}+\mathrm{H}]^{+}$

4-Hydroxy-2-oxo-3-phenyl-2,5-dihydropyrrole-1-carboxylic Acid tertButyl Ester (14) Potassium tert-butoxide ( $88 \mathrm{mg}, 0.78 \mathrm{mmol})$ was slowly added to a solution of $\mathbf{1 3}(200 \mathrm{mg}, 0.65 \mathrm{mmol})$ in DMF $(10 \mathrm{ml})$ and the mixture was stirred for $10 \mathrm{~min}$ at room temperature. Aqueous saturated ammonium chloride solution, water and ethyl acetate were added to the reaction mixture. The organic layer was separated, washed with water, dried and concentrated in vacuo. The resulting residue was triturated with diethyl ether and filtrated to afford $\mathbf{1 4}(120 \mathrm{mg}, 68 \%)$ as a solid. mp $152{ }^{\circ} \mathrm{C} .{ }^{1} \mathrm{H}-\mathrm{NMR}$ $\left(400 \mathrm{MHz}, \mathrm{DMSO}-d_{6}\right) \delta: 1.48(9 \mathrm{H}, \mathrm{s}), 4.27(2 \mathrm{H}, \mathrm{s}), 7.21(1 \mathrm{H}, \mathrm{t}, J=7.4 \mathrm{~Hz})$, $7.35(2 \mathrm{H}, \mathrm{t}, J=7.6 \mathrm{~Hz}), 7.85(2 \mathrm{H}, \mathrm{d}, J=7.2 \mathrm{~Hz}), 12.36(1 \mathrm{H}, \mathrm{br})$. IR (ATR) $\mathrm{cm}^{-1}:$ 3144, 1718, 1663, 1640, 1349, 1312, 1153, 694. MS (APCI): 276 $[\mathrm{M}+\mathrm{H}]^{+}$. Anal. Calcd for $\mathrm{C}_{15} \mathrm{H}_{17} \mathrm{NO}_{4}: \mathrm{C}, 65.44 ; \mathrm{H}, 6.22 ; \mathrm{N}, 5.09$. Found: C, $65.46 ; \mathrm{H}, 6.22 ; \mathrm{N}, 5.13$.

4-Methoxy-2-oxo-3-phenyl-2,5-dihydropyrrole-1-carboxylic Acid tertButyl Ester (15) Potassium carbonate $(30 \mathrm{~g}, 217.5 \mathrm{mmol})$ and dimethyl sulfate $(27 \mathrm{ml}, 290 \mathrm{mmol})$ were added to a solution of $\mathbf{1 4}$ in acetone (11) and the mixture was stirred for $3 \mathrm{~h}$ at reflux. Water and ethyl acetate were then added to the mixture and the organic layer was separated. The organic layer was dried and concentrated in vacuo. The resulting residue $15(39 \mathrm{~g}, 93 \%)$ was used for the next reaction without further purification. $m p 152{ }^{\circ} \mathrm{C} .{ }^{1} \mathrm{H}-$ NMR $\left(400 \mathrm{MHz}, \mathrm{DMSO}-d_{6}\right) \delta: 1.50(9 \mathrm{H}, \mathrm{s}), 4.01(3 \mathrm{H}, \mathrm{s}), 4.62(2 \mathrm{H}, \mathrm{s}), 7.25$ $(1 \mathrm{H}, \mathrm{t}, J=7.4 \mathrm{~Hz}), 7.37(2 \mathrm{H}, \mathrm{t}, J=7.6 \mathrm{~Hz}), 7.76(2 \mathrm{H}, \mathrm{d}, J=7.2 \mathrm{~Hz})$. IR (ATR) $\mathrm{cm}^{-1}:$ 2982, 1707, 1629, 1315, 1153, 1012, 781, 697. MS (APCI): 290 $[\mathrm{M}+\mathrm{H}]^{+}$. Anal. Calcd for $\mathrm{C}_{16} \mathrm{H}_{19} \mathrm{NO}_{4}$ : C, 66.42; H, 6.62; N, 4.84. Found: C, $66.46 ; \mathrm{H}, 6.62 ; \mathrm{N}, 4.91$.

4-Methoxy-3-phenyl-5-[1-pyridin-4-ylmeth-( $Z$-ylidene]-1,5-dihydropyrrol-2-one Hydrochloride (4a) $0.5 \mathrm{~m}$ Potassium hexamethyldisilazide in toluene $(8.9 \mathrm{ml}, 4.45 \mathrm{mmol})$ was slowly added to a solution of $\mathbf{1 5}$ $(1.0 \mathrm{~g}, 2.98 \mathrm{mmol})$ in THF $(20 \mathrm{ml})$ at $-78^{\circ} \mathrm{C}$ and the reaction mixture was stirred for $20 \mathrm{~min}$ at the same temperature, then at $0{ }^{\circ} \mathrm{C}$ for $10 \mathrm{~min}$. 4 Pyridinecarboxaldehyde $(0.43 \mathrm{ml}, 4.47 \mathrm{mmol})$ was slowly added to the reaction mixture at $-78^{\circ} \mathrm{C}$ and the mixture was stirred at $0^{\circ} \mathrm{C}$ for $2 \mathrm{~h}$. After aqueous saturated ammonium chloride solution was added to the reaction mixture, $\mathrm{CHCl}_{3}$ was added. The organic layer was separated, washed with water and brine, dried and concentrated in vacuo. The resulting residue was triturated with diethyl ether and filtrated. The crystals obtained were recrystallized from THF to give $120 \mathrm{mg}(14 \%)$ of 4-methoxy-3-phenyl-5-[1pyridin-4-ylmeth-(Z)-ylidene]-1,5-dihydropyrrol-2-one (16) as crystals. mp $232-234{ }^{\circ} \mathrm{C}$ (dec.)

To a solution of $16(120 \mathrm{mg}, 0.43 \mathrm{mmol})$ in THF $(20 \mathrm{ml})$ was added $4 \mathrm{~N}$ $\mathrm{HCl}$ in dioxane $(0.15 \mathrm{ml})$ and the mixture was stirred for $10 \mathrm{~min}$. The reaction mixture was then concentrated in vacuo. The resulting residue was triturated with diethyl ether and filtrated to afford $\mathbf{4 a}(50 \mathrm{mg}, 37 \%)$ as a solid. mp $227-228^{\circ} \mathrm{C}$ (dec.). ${ }^{1} \mathrm{H}-\mathrm{NMR}\left(400 \mathrm{MHz}, \mathrm{DMSO}-d_{6}\right) \delta: 3.78(3 \mathrm{H}, \mathrm{s}), 6.47$ $(1 \mathrm{H}, \mathrm{s}), 7.35-7.55(5 \mathrm{H}, \mathrm{m}), 8.11(2 \mathrm{H}, \mathrm{d}, J=6.8 \mathrm{~Hz}), 8.81 \quad(2 \mathrm{H}, \mathrm{d}$, $J=6.8 \mathrm{~Hz}), 10.72(1 \mathrm{H}, \mathrm{s})$. IR (ATR) $\mathrm{cm}^{-1}: 3354,3046,2742,2056,1702$, 1620, 1596, 1493, 1348, 1193, 1019, 870, 803, 698, 522. MS (APCI): 279 $[\mathrm{M}+\mathrm{H}]^{+}$. HR-MS-ESI Calcd for $\mathrm{C}_{17} \mathrm{H}_{15} \mathrm{~N}_{2} \mathrm{O}_{2}\left([\mathrm{M}+\mathrm{H}]^{+}\right)$: 279.1134. Found: 279.1126 .

\{3-[3-Methoxy-5-ox 0-4-phenyl-1,5-dihydropyrrol-(2Z)-ylidenemethyl]phenoxy acetic Acid (4b) $0.5 \mathrm{~m}$ Potassium hexamethyldisilazide in toluene $(72 \mathrm{ml}, 36 \mathrm{mmol})$ was slowly added to a solution of $15(7.0 \mathrm{~g}$, $24 \mathrm{mmol})$ in THF $(200 \mathrm{ml})$ at $-78^{\circ} \mathrm{C}$ and the reaction mixture was stirred at $-5^{\circ} \mathrm{C}$ for $30 \mathrm{~min}$. 3-Methoxymethoxybenzaldehyde $(3.7 \mathrm{~g}, 22.3 \mathrm{mmol})$ was added slowly to the reaction mixture at $-70^{\circ} \mathrm{C}$ and the mixture was stirred at $0^{\circ} \mathrm{C}$ for $2 \mathrm{~h}$ and at room temperature for $2 \mathrm{~h}$. After aqueous saturated ammonium chloride solution was added to the reaction mixture, ethyl acetate was added. The organic layer was separated, dried and concentrated in vacuo. The resulting residue was triturated with diethyl ether and filtrated. The crystals obtained were recrystallized from ethyl acetate to give $3.3 \mathrm{~g}$ (44\%) of 4-methoxy-5-[1-(3-methoxymethoxyphenyl)meth-( $Z$ )-ylidene]-3phenyl-1,5-dihydropyrrol-2-one (17) as crystals. mp $170-171{ }^{\circ} \mathrm{C}$. ${ }^{1} \mathrm{H}-\mathrm{NMR}$ $\left(400 \mathrm{MHz}, \mathrm{DMSO}-d_{6}\right) \delta: 3.39(3 \mathrm{H}, \mathrm{s}), 3.73(3 \mathrm{H}, \mathrm{s}), 5.27(2 \mathrm{H}, \mathrm{s}), 6.28(1 \mathrm{H}$ s), $6.96(1 \mathrm{H}, \mathrm{dd}, J=7.9,2.3 \mathrm{~Hz}), 7.21(1 \mathrm{H}, \mathrm{s}), 7.24(1 \mathrm{H}, \mathrm{d}, J=7.9 \mathrm{~Hz}), 7.30$
$(1 \mathrm{H}, \mathrm{d}, J=7.9 \mathrm{~Hz}), 7.32-7.47(3 \mathrm{H}, \mathrm{m}), 7.52-7.56(2 \mathrm{H}, \mathrm{m}), 10.09(1 \mathrm{H}, \mathrm{s})$. IR (ATR) $\mathrm{cm}^{-1}: 3174,1674,1656,1626,1594,1349,1224,1149,1009$, 780, 682, 647, 448. MS (APCI): $338[\mathrm{M}+\mathrm{H}]^{+}$.

To a $17(2.8 \mathrm{~g}, 8.3 \mathrm{mmol})$ solution in THF $(100 \mathrm{ml})$ was added $6 \mathrm{~N}$ aqueous $\mathrm{HCl}$ solution $(10 \mathrm{ml})$ and the mixture was stirred at $50{ }^{\circ} \mathrm{C}$ for $2 \mathrm{~h}$. After water and ethyl acetate were added to the mixture, the organic layer was separated, dried and concentrated in vacuo. The resulting residue was triturated with diethyl ether and filtrated to give $2.1 \mathrm{~g}(86 \%)$ of 5-[1-(3-hydroxyphenyl)meth-(Z)-ylidene]-4-methoxy-3-phenyl-1,5-dihydropyrrol-2-one (18) as a solid. mp $188-189^{\circ} \mathrm{C} .{ }^{1} \mathrm{H}-\mathrm{NMR}\left(400 \mathrm{MHz}, \mathrm{DMSO}-d_{6}\right) \delta: 3.73(3 \mathrm{H}, \mathrm{s})$, $6.22(1 \mathrm{H}, \mathrm{s}), 6.72(1 \mathrm{H}, \mathrm{dd}, J=8.0,2.3 \mathrm{~Hz}), 6.94(1 \mathrm{H}, \mathrm{s}), 7.06(1 \mathrm{H}, \mathrm{d}$, $J=8.0 \mathrm{~Hz}), 7.19(1 \mathrm{H}, \mathrm{t}, J=8.0 \mathrm{~Hz}), 7.32-7.46(3 \mathrm{H}, \mathrm{m}), 7.50-7.57(2 \mathrm{H}$, m), $9.46(1 \mathrm{H}, \mathrm{s}), 9.94(1 \mathrm{H}, \mathrm{s})$. IR (ATR) $\mathrm{cm}^{-1}: 3314,1656,1594,1451$, 1361, 1231, 965, 738, 639. MS (APCI): $294[\mathrm{M}+\mathrm{H}]^{+}$

$60 \%$ Sodium hydride in oil $(300 \mathrm{mg}, 7.5 \mathrm{mmol})$ was slowly added to a solution of $18(1.8 \mathrm{~g}, 6.1 \mathrm{mmol})$ in DMF $(50 \mathrm{ml})$. The mixture was stirred at room temperature for $1 \mathrm{~h}$ and bromoacetic acid tert-butyl ester $(2.3 \mathrm{~g}$, $11.8 \mathrm{mmol}$ ) was added. After the addition, the mixture was further stirred at room temperature for $16 \mathrm{~h}$. Water and ethyl acetate were added to the mixture and the organic layer was separated. The organic layer was washed with water, dried and concentrated in vacuo. The resulting residue was chromatographed on silica gel to give $1.2 \mathrm{~g}(43 \%)$ of $\{3-[3-$ methoxy-5-oxo-4phenyl-1,5-dihydropyrrol-(2Z)-ylidenemethyl]phenoxy $\}$ acetic acid tert-butyl ester (19) as a solid. mp 167-168 ${ }^{\circ} \mathrm{C} .{ }^{1} \mathrm{H}-\mathrm{NMR}\left(200 \mathrm{MHz}, \mathrm{CDCl}_{3}\right) \delta: 1.49$ $(9 \mathrm{H}, \mathrm{s}), 3.78(3 \mathrm{H}, \mathrm{s}), 4.53(2 \mathrm{H}, \mathrm{s}), 6.34(1 \mathrm{H}, \mathrm{s}), 6.83(1 \mathrm{H}, \mathrm{dd}, J=8.2$, $2.5 \mathrm{~Hz}), 6.95(1 \mathrm{H}, \mathrm{br}), 7.05(1 \mathrm{H}, \mathrm{d}, J=7.7 \mathrm{~Hz}), 7.32(1 \mathrm{H}, \mathrm{d}, J=8.2 \mathrm{~Hz})$, $7.34-7.56(5 \mathrm{H}, \mathrm{m}), 7.71(1 \mathrm{H}, \mathrm{br})$.

Trifluoroacetic acid $(1 \mathrm{ml})$ was added to a solution of $19(900 \mathrm{mg}$, $2.21 \mathrm{mmol})$ in $\mathrm{CH}_{2} \mathrm{Cl}_{2}(1 \mathrm{ml})$ and the reaction mixture was stirred at room temperature for $2 \mathrm{~h}$. After the mixture was concentrated in vacuo, the resulting residue was triturated with diethyl ether and filtrated to give $720 \mathrm{mg}$ $(93 \%)$ of $4 \mathbf{b}$ as a solid. mp $224-226{ }^{\circ} \mathrm{C} .{ }^{1} \mathrm{H}-\mathrm{NMR}\left(400 \mathrm{MHz}, \mathrm{DMSO}-d_{6}\right) \delta$ : $3.73(3 \mathrm{H}, \mathrm{s}), 4.79(2 \mathrm{H}, \mathrm{s}), 6.29(1 \mathrm{H}, \mathrm{s}), 6.86(1 \mathrm{H}, \mathrm{dd}, J=8.2,2.3 \mathrm{~Hz}), 7.09$ $(1 \mathrm{H}, \mathrm{s}), 7.20(1 \mathrm{H}, \mathrm{d}, J=7.9 \mathrm{~Hz}), 7.30(1 \mathrm{H}, \mathrm{t}, J=7.9 \mathrm{~Hz}), 7.33-7.39(1 \mathrm{H}, \mathrm{m})$, $7.43(2 \mathrm{H}, \mathrm{t}, J=7.0 \mathrm{~Hz}), 7.54(2 \mathrm{H}, \mathrm{d}, J=7.0 \mathrm{~Hz}), 10.14(1 \mathrm{H}, \mathrm{s})$. IR (ATR) $\mathrm{cm}^{-1}: 3240,2861,2503,1884,1702,1658,1618,1590,1299,1228,973$, 655, 506. MS (APCI): $352[\mathrm{M}+\mathrm{H}]^{+}$. HR-MS-ESI Calcd for $\mathrm{C}_{20} \mathrm{H}_{18} \mathrm{NO}_{5}$ $\left([\mathrm{M}+\mathrm{H}]^{+}\right)$: 352.1185. Found: 352.1169. Anal. Calcd for $\mathrm{C}_{20} \mathrm{H}_{17} \mathrm{NO}_{5}: \mathrm{C}$, 68.37; H, 4.88; N, 3.99. Found: C, 68.28; H, 4.77; N, 4.05.

3,4-Diphenyl-1,5-dihydropyrrol-2-one (6) Triethylamine (150 ml, $1.08 \mathrm{~mol})$ was slowly added to a suspension of $\mathrm{N}$-(2-oxo-2-phenylethyl)-2phenylacetamide $20(32.4 \mathrm{~g}, 128 \mathrm{mmol})$ in acetic anhydride $(150 \mathrm{ml})$ at $0{ }^{\circ} \mathrm{C}$. After the reaction mixture was stirred at room temperature for $13 \mathrm{~h}$, the mixture was concentrated in vacuo. Water and ethyl acetate were added to the residue, and the organic layer was separated, washed with aqueous saturated citric acid solution, aqueous saturated $\mathrm{NaHCO}_{3}$ solution and brine, dried and concentrated in vacuo. Toluene $(100 \mathrm{ml})$ was then added to the resulting residue, and the mixture was concentrated in vacuo. The residue was triturated with diethyl ether and filtrated to give $28.2 \mathrm{~g}(80 \%)$ of 1-acetyl-3,4diphenyl-1,5-dihydropyrrol-2-one $(\mathbf{2 1})$ as a solid. $\mathrm{mp} 154-155^{\circ} \mathrm{C}$. ${ }^{1} \mathrm{H}$ NMR (400 MHz, DMSO- $\left.d_{6}\right) \delta: 2.51(3 \mathrm{H}, \mathrm{s}), 4.81(2 \mathrm{H}, \mathrm{s}), 7.25-7.45(10 \mathrm{H}$, m). IR (ATR) $\mathrm{cm}^{-1}: 3059,1707,1688,1639,1371,1333,1291,691$. MS (APCI): $278[\mathrm{M}+\mathrm{H}]^{+}$

$28 \%$ Sodium methoxide in $\mathrm{MeOH}(13.6 \mathrm{ml}, 65.1 \mathrm{mmol})$ was slowly added to a suspension of $21(17.19 \mathrm{~g}, 62 \mathrm{mmol})$ in $\mathrm{MeOH}(400 \mathrm{ml})$ at $0{ }^{\circ} \mathrm{C}$ and the reaction mixture was stirred at the same temperature for $1 \mathrm{~h}$. After slow addition of acetic acid $(3.71 \mathrm{ml}, 65.1 \mathrm{mmol})$ to the mixture, the mixture was concentrated in vacuo. Water and $\mathrm{CH}_{2} \mathrm{Cl}_{2}$ were added to the residue, and the organic layer was separated, washed with brine, dried and concentrated in vacuo. The resulting residue was triturated with diethyl ether and filtrated to give $14.01 \mathrm{~g}(96 \%)$ of 6 as a solid. mp $184-185^{\circ} \mathrm{C} .{ }^{1} \mathrm{H}-\mathrm{NMR}(400 \mathrm{MHz}$, DMSO- $\left.d_{6}\right) \delta: 4.37(2 \mathrm{H}, \mathrm{s}), 7.25-7.40(10 \mathrm{H}, \mathrm{m}), 8.52(1 \mathrm{H}, \mathrm{s})$. IR (ATR) $\mathrm{cm}^{-1}: 3189,3059,1681,1444,1368,762,743,702,689$. MS (APCI): 236 $[\mathrm{M}+\mathrm{H}]^{+}$. HR-MS-ESI Calcd for $\mathrm{C}_{16} \mathrm{H}_{14} \mathrm{NO}\left([\mathrm{M}+\mathrm{H}]^{+}\right)$: 236.1075. Found: 236.1067 .

2-Oxo-3,4-dipenyl-2,5-dihydropyrrole-1-carboxylic Acid tert-Butylester (22) (Boc) $)_{2} \mathrm{O}(12.44 \mathrm{~g}, 57 \mathrm{mmol})$ and $\mathrm{N}, \mathrm{N}$-dimethyl-4-aminopyridine $(348 \mathrm{mg}, 2.85 \mathrm{mmol})$ were added to a suspension of $6(6.71 \mathrm{~g}$, $28.5 \mathrm{~mol})$ in acetonitrile $(300 \mathrm{ml})$ at $0^{\circ} \mathrm{C}$ and the mixture was stirred at room temperature for $3 \mathrm{~h}$. Water and ethyl acetate were then added to the mixture, and the organic layer was separated. The organic layer was washed with brine, dried and concentrated in vacuo. The resulting residue was chromatographed on silica gel to give $2.44 \mathrm{~g}(26 \%)$ of 22 as a solid. mp 144 $146{ }^{\circ} \mathrm{C} .{ }^{1} \mathrm{H}-\mathrm{NMR}\left(400 \mathrm{MHz}, \mathrm{DMSO}-d_{6}\right) \delta: 1.52(9 \mathrm{H}, \mathrm{s}), 4.78(2 \mathrm{H}, \mathrm{s}), 7.22$ 
$7.27(2 \mathrm{H}, \mathrm{m}), 7.32-7.43(8 \mathrm{H}, \mathrm{m})$. IR (ATR) $\mathrm{cm}^{-1}: 2978,1764,1349,1297$, 1160, 913, 691. MS (APCI): $336[\mathrm{M}+\mathrm{H}]^{+}$. Anal. Calcd for $\mathrm{C}_{21} \mathrm{H}_{21} \mathrm{NO}_{3}: \mathrm{C}$, 75.20; H, 6.31; N, 4.18. Found: C, 74.90; H, 6.29; N, 3.99.

3,4-Diphenyl-5-[1-phenylmeth-( $Z$ )-ylidene]-1,5-dihydropyrrol-2-one (5a) $0.5 \mathrm{~m}$ Potassium hexamethyldisilazide in toluene $(7.2 \mathrm{ml}, 3.6 \mathrm{mmol})$ was slowly added to a solution of $\mathbf{2 1}(500 \mathrm{mg}, 1.8 \mathrm{mmol})$ and benzaldehyde $(0.27 \mathrm{ml}, 2.7 \mathrm{mmol})$ in $\mathrm{THF}(20 \mathrm{ml})$ at $-78^{\circ} \mathrm{C}$ and the reaction mixture was stirred at $-78^{\circ} \mathrm{C}$ for $30 \mathrm{~min}$ and at room temperature for $12 \mathrm{~h}$. After aqueous saturated ammonium chloride solution was added to the reaction mixture, ethyl acetate was added. The organic layer was separated, dried and concentrated in vacuo. The resulting residue was triturated with diisopropyl ether and filtrated. The crystals obtained were recrystallized from ethyl acetate, THF and diisopropyl ether to give $156 \mathrm{mg}(27 \%)$ of $\mathbf{5 a}$ as crystals. $\mathrm{mp}$ $243-244{ }^{\circ} \mathrm{C} .{ }^{1} \mathrm{H}-\mathrm{NMR}\left(400 \mathrm{MHz}, \mathrm{DMSO}-d_{6}\right) \delta: 5.84(1 \mathrm{H}, \mathrm{s}), 7.23-7.34$ $(8 \mathrm{H}, \mathrm{m}), 7.38(2 \mathrm{H}, \mathrm{t}, J=7.5 \mathrm{~Hz}), 7.44-7.49(3 \mathrm{H}, \mathrm{m}), 7.54(2 \mathrm{H}, \mathrm{d}$, $J=7.5 \mathrm{~Hz}$ ), $10.63(1 \mathrm{H}, \mathrm{s})$. IR (ATR) $\mathrm{cm}^{-1}: 3217,1682,1635,1222,795$, 730, 683, 641, 517. MS (APCI): $324[\mathrm{M}+\mathrm{H}]^{+}$. HR-MS-ESI Calcd for $\mathrm{C}_{23} \mathrm{H}_{18} \mathrm{NO}\left([\mathrm{M}+\mathrm{H}]^{+}\right): 324.1388$. Found: 324.1379 .

3,4-Diphenyl-5-[1-pyridin-4-ylmeth-( $Z$ )-ylidene]-1,5-dihydropyrrol-2one (5b) This compound, prepared from 22 and 4-pyridinecaeboxaldehyde as described in the synthesis of 16, was obtained as crystals. Yield $46 \%$. mp $236-237^{\circ} \mathrm{C}$ (dec.). ${ }^{1} \mathrm{H}-\mathrm{NMR}\left(400 \mathrm{MHz}, \mathrm{DMSO}-d_{6}\right) \delta: 5.78(1 \mathrm{H}, \mathrm{s}), 7.25-$ $7.35(7 \mathrm{H}, \mathrm{m}), 7.45-7.52(5 \mathrm{H}, \mathrm{m}), 8.54(2 \mathrm{H}, \mathrm{d}, J=6.1 \mathrm{~Hz}), 10.80(1 \mathrm{H}, \mathrm{s}) . \mathrm{IR}$ (ATR) $\mathrm{cm}^{-1}: 3199,3056,1699,1636,1598,1440,1207,692,639,481 . \mathrm{MS}$ (APCI): $325[\mathrm{M}+\mathrm{H}]^{+}$. HR-MS-ESI Calcd for $\mathrm{C}_{22} \mathrm{H}_{17} \mathrm{~N}_{2} \mathrm{O}\left([\mathrm{M}+\mathrm{H}]^{+}\right)$: 325.1341. Found: 325.1346.

3,4-Diphenyl-5-[1-pyridin-3-ylmeth-( $Z$ )-ylidene]-1,5-dihydropyrrol-2one $(5 \mathrm{c})$ This compound, prepared from 22 and 3-pyridinecaeboxaldehyde as described in the synthesis of 16, was obtained as crystals. Yield $29 \%$. mp $239-240{ }^{\circ} \mathrm{C} .{ }^{1} \mathrm{H}-\mathrm{NMR}\left(400 \mathrm{MHz}, \mathrm{DMSO}-d_{6}\right) \delta: 5.86(1 \mathrm{H}, \mathrm{s}), 7.23-7.37$ $(7 \mathrm{H}, \mathrm{m}), 7.40(1 \mathrm{H}, \mathrm{dd}, J=7.5,4.7 \mathrm{~Hz}), 7.43-7.52(3 \mathrm{H}, \mathrm{m}), 8.00(1 \mathrm{H}, \mathrm{d}$, $J=8.2 \mathrm{~Hz}), 8.46(1 \mathrm{H}, \mathrm{d}, J=4.1 \mathrm{~Hz}), 8.66(1 \mathrm{H}, \mathrm{s}), 10.77(1 \mathrm{H}, \mathrm{s})$. IR (ATR) $\mathrm{cm}^{-1}:$ 3199, 1677, 1442, 1217, 796, 731, 691, 515. MS (APCI): 325 $[\mathrm{M}+\mathrm{H}]^{+}$. HR-MS-ESI Calcd for $\mathrm{C}_{22} \mathrm{H}_{17} \mathrm{~N}_{2} \mathrm{O}\left([\mathrm{M}+\mathrm{H}]^{+}\right)$: 325.1341. Found: 325.1339

5-[1-(3-Hydroxyphenyl)meth-(Z)-ylidene]-3,4-diphenyl-1,5-dihydropyrrol-2-one (5d) This compound, prepared from 22 and 3-methoxymethoxybenzaldehyde as described in the synthesis of 18, was obtained as a solid. Yield 38\%. mp 226-227 ${ }^{\circ} \mathrm{C} .{ }^{1} \mathrm{H}-\mathrm{NMR}\left(400 \mathrm{MHz}, \mathrm{DMSO}-d_{6}\right) \delta: 5.75$ $(1 \mathrm{H}, \mathrm{s}), 6.71(1 \mathrm{H}, \mathrm{dd}, J=7.9,2.1 \mathrm{~Hz}), 6.86(1 \mathrm{H}, \mathrm{s}), 6.99(1 \mathrm{H}, \mathrm{d}, J=7.9 \mathrm{~Hz})$, $7.18(1 \mathrm{H}, \mathrm{t}, J=7.9 \mathrm{~Hz}), 7.22-7.34(7 \mathrm{H}, \mathrm{m}), 7.43-7.49(3 \mathrm{H}, \mathrm{m}), 9.48(1 \mathrm{H}$, s), $10.51(1 \mathrm{H}, \mathrm{s})$. IR (ATR) $\mathrm{cm}^{-1}: 3419,3259,3061,1683,1578,1216,727$, 683, 642. MS (APCI): $340[\mathrm{M}+\mathrm{H}]^{+}$. HR-MS-ESI Calcd for $\mathrm{C}_{23} \mathrm{H}_{18} \mathrm{NO}_{2}$ $\left([\mathrm{M}+\mathrm{H}]^{+}\right): 340.1338$. Found: 340.1324 .

5-[1-(3-Dimethoxymethylphenyl)meth-(Z)-ylidene]-3,4-diphenyl-1,5dihydropyrrol-2-one (5e) This compound, prepared from 22 and 3 dimethoxymethylbenzaldehyde as described in the synthesis of 16, was obtained as crystals. Yield 55\%. mp 235-236 ${ }^{\circ} \mathrm{C} .{ }^{1} \mathrm{H}-\mathrm{NMR}(400 \mathrm{MHz}$, DMSO- $\left.d_{6}\right) \delta: 3.25(6 \mathrm{H}, \mathrm{s}), 5.39(1 \mathrm{H}, \mathrm{s}), 5.85(1 \mathrm{H}, \mathrm{s}), 7.23-7.35(8 \mathrm{H}, \mathrm{m})$, $7.40(1 \mathrm{H}, \mathrm{t}, J=7.8 \mathrm{~Hz}), 7.44-7.50(4 \mathrm{H}, \mathrm{m}), 7.57(1 \mathrm{H}, \mathrm{d}, J=7.8 \mathrm{~Hz}), 10.67$ (1H, s). IR (ATR) $\mathrm{cm}^{-1}: 3209,2948,1682,1361,1049,794,734,693,642$. MS (APCI): $398[\mathrm{M}+\mathrm{H}]^{+}$. HR-MS-ESI Calcd for $\mathrm{C}_{26} \mathrm{H}_{24} \mathrm{NO}_{3}\left([\mathrm{M}+\mathrm{H}]^{+}\right)$: 398.1756. Found: 398.1737. Anal. Calcd for $\mathrm{C}_{26} \mathrm{H}_{23} \mathrm{NO}_{3}$ : C, 78.57; H, 5.83; N, 3.52. Found: C, 78.55; H, 5.94; N, 3.62.

\{3-[5-Oxo-3,4-diphenyl-1,5-dihydropyrrol-(2Z)-ylidenemethyl]phenoxy acetic Acid Sodium Salt (5f) Following the synthetic method of $\mathbf{4 b}$, \{3-[5-oxo-3,4-diphenyl-1,5-dihydropyrrol-(2Z)-ylidenemethyl]phenoxy\}acetic acid (free form) was prepared from 5d as crystals. Yield 61\%. mp 247 $248^{\circ} \mathrm{C}$. To a $397.5 \mathrm{mg}(1 \mathrm{mmol})$ of free form solution in $\mathrm{MeOH}(10 \mathrm{ml})$ was added $2 \mathrm{~N} \mathrm{NaOH}$ aqueous solution $(0.5 \mathrm{ml})$. After the reaction mixture was stirred for $10 \mathrm{~min}$ at room temperature, the mixture was concentrated in vacuo. The resulting residue was triturated with diethyl ether and filtrated to give $419 \mathrm{mg}$ (quant.) of $\mathbf{5 f}$ as a solid. $\mathrm{mp}>320{ }^{\circ} \mathrm{C}$. ${ }^{1} \mathrm{H}-\mathrm{NMR}(400 \mathrm{MHz}$, DMSO- $\left.d_{6}\right) \delta: 4.16(2 \mathrm{H}, \mathrm{s}), 5.78(1 \mathrm{H}, \mathrm{s}), 6.76(1 \mathrm{H}, \mathrm{dd}, J=8.1,2.2 \mathrm{~Hz}), 6.90$ $(1 \mathrm{H}, \mathrm{s}), 7.02(1 \mathrm{H}, \mathrm{d}, J=7.7 \mathrm{~Hz}), 7.21(1 \mathrm{H}, \mathrm{t}, J=8.1 \mathrm{~Hz}), 7.23-7.35(7 \mathrm{H}, \mathrm{m})$ $7.42-7.49(3 \mathrm{H}, \mathrm{m}), 10.59(1 \mathrm{H}, \mathrm{s})$. IR (ATR) $\mathrm{cm}^{-1}: 3242,1690,1601,1426$, 1219, 687. MS (APCI): $396[\mathrm{M}-\mathrm{Na}]^{-}$. HR-MS-ESI Calcd for $\mathrm{C}_{25} \mathrm{H}_{20} \mathrm{NO}_{4}$ $\left([\mathrm{M}+\mathrm{H}]^{+}\right): 398.1392$. Found: 398.1396.

\{4-[5-Oxo-3,4-diphenyl-1,5-dihydropyrrol-(2Z)-ylidenemethyl]phenoxy $\}$ acetic Acid Sodium Salt (5g) This compound, prepared from 22 and 4-formylphenoxyacetic acid tert-butyl ester as described in the synthesis of $\mathbf{1 6}$ and $\mathbf{5 f}$, was obtained as a solid. Yield $46 \%$. mp $270-275^{\circ} \mathrm{C}$ (dec.). ${ }^{1} \mathrm{H}-\mathrm{NMR}\left(400 \mathrm{MHz}, \mathrm{DMSO}-d_{6}\right) \delta: 4.09(2 \mathrm{H}, \mathrm{s}), 5.78(1 \mathrm{H}, \mathrm{s}), 6.78(2 \mathrm{H}, \mathrm{d}$, $J=8.7 \mathrm{~Hz}), 7.21-7.32(7 \mathrm{H}, \mathrm{m}), 7.42-7.49(5 \mathrm{H}, \mathrm{m}), 10.53(1 \mathrm{H}, \mathrm{s})$. IR
(ATR) $\mathrm{cm}^{-1}: 3163,1672,1583,1421,1246,1181,1044,691$. MS (APCI): $396[\mathrm{M}-\mathrm{Na}]^{-}$. HR-MS-ESI Calcd for $\mathrm{C}_{25} \mathrm{H}_{20} \mathrm{NO}_{4}\left([\mathrm{M}+\mathrm{H}]^{+}\right): 398.1392$. Found: 398.1392 .

\{2-[5-Oxo-3,4-diphenyl-1,5-dihydropyrrol-(2Z)-ylidenemethyl]phenoxy $\}$ acetic Acid Sodium Salt (5h) This compound, prepared from 22 and 2-formylphenoxyacetic acid tert-butyl ester as described in the synthesis of $\mathbf{1 6}$ and $\mathbf{5 f}$, was obtained as a solid. Yield 67\%. mp $357-360{ }^{\circ} \mathrm{C}$ (dec.). ${ }^{1} \mathrm{H}-\mathrm{NMR}\left(400 \mathrm{MHz}, \mathrm{DMSO}-d_{6}\right) \delta: 4.52(2 \mathrm{H}, \mathrm{s}), 5.92(1 \mathrm{H}, \mathrm{s}), 6.86-6.94$ $(2 \mathrm{H}, \mathrm{m}), 7.17-7.35(9 \mathrm{H}, \mathrm{m}), 7.40-7.47(3 \mathrm{H}, \mathrm{m}), 11.66(1 \mathrm{H}, \mathrm{s})$. IR (ATR) $\mathrm{cm}^{-1}: 3196,1683,1624,1576,1495,1442,798,744,731,695,639 . \mathrm{MS}$ (APCI): $396[\mathrm{M}-\mathrm{Na}]^{-}$. HR-MS-ESI Calcd for $\mathrm{C}_{25} \mathrm{H}_{20} \mathrm{NO}_{4}\left([\mathrm{M}+\mathrm{H}]^{+}\right)$: 398.1392. Found: 398.1377 .

\{3-[3-Furan-2-yl-5-oxo-4-phenyl-1,5-dihydropyrrol-(2Z)-ylidenemethyl]phenoxy\}acetic Acid (5i) This compound, prepared from 4-(2furyl)-3-phenyl-1,5-dihydropyrrol-2-one $27^{24}$ and 3-formylphenoxyacetic acid tert-butyl ester as described in the synthesis of $\mathbf{5} \mathbf{j}$, was obtained as a solid. Yield $60 \%$. mp $214-216{ }^{\circ} \mathrm{C} .{ }^{1} \mathrm{H}-\mathrm{NMR}\left(400 \mathrm{MHz}, \mathrm{DMSO}-d_{6}\right) \delta: 4.80$ $(2 \mathrm{H}, \mathrm{s}), 6.45(1 \mathrm{H}, \mathrm{s}), 6.68(1 \mathrm{H}, \mathrm{dd}, J=3.4,1.8 \mathrm{~Hz}), 6.77(1 \mathrm{H}, \mathrm{d}, J=3.4 \mathrm{~Hz})$, $6.90(1 \mathrm{H}, \mathrm{dd}, J=8.1,2.4 \mathrm{~Hz}), 7.10-7.45(8 \mathrm{H}, \mathrm{m}), 7.82(1 \mathrm{H}, \mathrm{d}, J=1.8 \mathrm{~Hz})$, $10.69(1 \mathrm{H}, \mathrm{s})$. IR (ATR) $\mathrm{cm}^{-1}: 3237,2504,1702,1641,1300,682 . \mathrm{MS}$ (APCI): $388[\mathrm{M}+\mathrm{H}]^{+}$. HR-MS-ESI Calcd for $\mathrm{C}_{23} \mathrm{H}_{18} \mathrm{NO}_{5}\left([\mathrm{M}+\mathrm{H}]^{+}\right)$: 388.1185. Found: 388.1184 .

\{3-[5-Oxo-4-phenyl-3-thiophen-2-yl-1,5-dihydropyrrol-(2Z)-ylidenemethyl]phenoxy\}acetic Acid (5j) 1,1'-Carbonyldiimidazole (12.16 g, $75 \mathrm{mmol}$ ) was added to a suspension of phenylacetic acid $(9.72 \mathrm{~g}$, $71.4 \mathrm{mmol})$ in $\mathrm{CH}_{2} \mathrm{Cl}_{2}(70 \mathrm{ml})$ at room temperature and the mixture was stirred for $30 \mathrm{~min}$. Triethylamine $(11.94 \mathrm{ml}, 85.68 \mathrm{mmol})$ and 2-amino-1-(2thiophenyl)ethanone hydrochloride $28(12.68 \mathrm{~g}, 71.4 \mathrm{mmol})$ were then added to the mixture at $0{ }^{\circ} \mathrm{C}$. After the reaction mixture was stirred at room temperature for $14 \mathrm{~h}$, aqueous $5 \%$ citric acid solution was added. The organic layer was separated, washed with aqueous saturated $\mathrm{NaHCO}_{3}$ solution and brine, dried and concentrated in vacuo. The residue was triturated with EtOH and filtrated to give $12.34 \mathrm{~g}$ (67\%) of $\mathrm{N}$-[2-oxo-2-(2-thiophenyl)ethyl]-2-phenylacetamide 29 as a solid. mp 90-92 ${ }^{\circ} \mathrm{C} .{ }^{1} \mathrm{H}-\mathrm{NMR}(400 \mathrm{MHz}$, DMSO- $\left.d_{6}\right) \delta: 3.53(2 \mathrm{H}, \mathrm{s}), 4.54(2 \mathrm{H}, \mathrm{d}, J=5.6 \mathrm{~Hz}), 7.19-7.34(6 \mathrm{H}, \mathrm{m})$, $8.04(2 \mathrm{H}, \mathrm{d}, J=4.6 \mathrm{~Hz}), 8.48(1 \mathrm{H}, \mathrm{t}, J=5.6 \mathrm{~Hz})$. IR (ATR) $\mathrm{cm}^{-1}: 3380,3097$, 1650, 1512, 1415, 1236, 723, 513, 478. MS (APCI): $260[\mathrm{M}+\mathrm{H}]^{+}$. Anal. Calcd for $\mathrm{C}_{14} \mathrm{H}_{13} \mathrm{NO}_{2} \mathrm{~S}: \mathrm{C}, 64.84 ; \mathrm{H}, 5.05 ; \mathrm{N}, 5.40 ; \mathrm{S}, 12.37$. Found: C, 64.46; H, 5.00; N, 5.36; S, 12.31

$95 \%$ Sodium methoxide $(6.55 \mathrm{~g}, 115.2 \mathrm{mmol})$ was added to 29 (14.94 g, $57.6 \mathrm{mmol})$ in $\mathrm{EtOH}(50 \mathrm{ml})$ and the mixture was stirred at reflux for $30 \mathrm{~min}$. After slow addition of acetic acid $(6.57 \mathrm{ml}, 115.2 \mathrm{mmol})$ to the mixture at $0{ }^{\circ} \mathrm{C}$, the mixture was concentrated in vacuo. Water and $\mathrm{CH}_{2} \mathrm{Cl}_{2}$ were then added to the residue, and the organic layer was separated, washed with brine, dried and concentrated in vacuo. The resulting residue was triturated with $\mathrm{MeOH}$ and filtrated to give $7.91 \mathrm{~g}$ (57\%) of 3-phenyl-4-(2-thiophenyl)-1,5dihydropyrrol-2-one 30 as a solid. mp $224-227{ }^{\circ} \mathrm{C} .{ }^{1} \mathrm{H}-\mathrm{NMR}(400 \mathrm{MHz}$, DMSO- $\left.d_{6}\right) \delta: 4.42(2 \mathrm{H}, \mathrm{s}), 7.07(1 \mathrm{H}, \mathrm{dd}, J=5.1,3.8 \mathrm{~Hz}), 7.29-7.36(3 \mathrm{H}$, m), $7.38-7.48(3 \mathrm{H}, \mathrm{m}), 7.56(1 \mathrm{H}, \mathrm{d}, J=5.1 \mathrm{~Hz}), 8.38(1 \mathrm{H}, \mathrm{s})$. IR (ATR) $\mathrm{cm}^{-1}: 3170,3050,1677,725,697 . \mathrm{MS}$ (APCI): $242[\mathrm{M}+\mathrm{H}]^{+}$

A solution of $\mathrm{NaOH}(260 \mathrm{mg}, 6.5 \mathrm{mmol})$ in water $(1 \mathrm{ml})$ was added to a suspension of 30 (145 $\mathrm{mg}, 0.6 \mathrm{mmol})$ and 3-formylphenoxyacetic acid tertbutyl ester $(118 \mathrm{mg}, 0.5 \mathrm{mmol})$ in $\mathrm{MeOH}(2.5 \mathrm{ml})$. After stirring the mixture at room temperature for $16 \mathrm{~h}, 2 \mathrm{~N} \mathrm{HCl}$ aqueous solution $(3.25 \mathrm{ml})$ was added, and the reaction mixture was concentrated in vacuo. Water and $\mathrm{CHCl}_{3}$ were then added to the residue. The organic layer was separated, washed with aqueous 5\% citric acid solution, dried and concentrated in vacuo. The residue was triturated with $\mathrm{MeOH}$ and filtrated to give $175 \mathrm{mg}(87 \%)$ of $\mathbf{5 j}$ as a solid. mp $261-263{ }^{\circ} \mathrm{C} .{ }^{1} \mathrm{H}-\mathrm{NMR}\left(400 \mathrm{MHz}, \mathrm{DMSO}-d_{6}\right) \delta: 4.79(2 \mathrm{H}, \mathrm{s})$, $6.17(1 \mathrm{H}, \mathrm{s}), 6.88(1 \mathrm{H}, \mathrm{dd}, J=8.2,2.3 \mathrm{~Hz}), 7.08(1 \mathrm{H}, \mathrm{s}), 7.16(1 \mathrm{H}, \mathrm{d}$, $J=7.6 \mathrm{~Hz}), 7.18-7.38(8 \mathrm{H}, \mathrm{m}), 7.75(1 \mathrm{H}, \mathrm{d}, J=4.9 \mathrm{~Hz}), 10.75(1 \mathrm{H}, \mathrm{s}) . \mathrm{IR}$ (ATR) $\mathrm{cm}^{-1}: 3218,2499,1890,1705,1646,1622,1307,793,687,652,442$. MS (APCI): $404[\mathrm{M}+\mathrm{H}]^{+}$. HR-MS-ESI Calcd for $\mathrm{C}_{23} \mathrm{H}_{18} \mathrm{NO}_{4} \mathrm{~S}\left([\mathrm{M}+\mathrm{H}]^{+}\right)$: 404.0957. Found: 404.0960. Anal. Calcd for $\mathrm{C}_{23} \mathrm{H}_{17} \mathrm{NO}_{4} \mathrm{~S}$ : C, 68.47; H, 4.25; N, 3.47; S, 7.95. Found: C, 68.17; H, 4.33; N, 3.67.

Inhibitory Effect on the Reaction of Human PAI-1 with t-PA The experiment was performed according to the method of Keijer et al. ${ }^{25)}$ Inhibition of the interaction between t-PA and PAI-1 was determined by measuring residual t-PA activity. Twenty-five microliters of t-PA solution (final conc. $0.2 \mathrm{~nm}$ ) and $25 \mu \mathrm{l}$ of assay buffer or PAI- 1 solution (PAI-1 was added so as to inhibit t-PA activity by $75 \%$ in the absence of test compound) were mixed and incubated with $2.5 \mu \mathrm{l}$ of a test compound solution (dissolved in DMSO) at $25^{\circ} \mathrm{C}$ for $15 \mathrm{~min}$. Two hundred microliters of a chromogenic substrate solution (S-2288: H-D-iie-Pro-Arg-pNA) was then added to the mixture, and 
the whole was incubated at $37^{\circ} \mathrm{C}$. The increase in absorbance at $405 \mathrm{~nm}$ was continuously (every $5 \mathrm{~min}$ ) monitored for $2 \mathrm{~h}$ with a microplatereader and $\mathrm{DA} / \mathrm{D}$ min was calculated. The $\mathrm{IC}_{50}$ value was estimated as the concentration that inhibits PAI- 1 activity by $50 \%$.

Antithrombotic Activity of 5 f (T-1776Na) in a Rat Model of Arterial

Thrombosis Thrombus was induced in the abdominal aorta by electrical stimulation. $^{26)}$ On the day before the experiment, a catheter-type platinum electrode was implanted into the abdominal aorta through the left femoral artery under Nembutal (Abbot, $50 \mathrm{mg} / \mathrm{kg}$, ip) anesthesia. After the end of the electrode was exteriorized at the back of the neck, a plate-type silver-silver chloride was implanted subcutaneously at the back of the neck at the opposite pole. After suturing the incisions, an electric cell and a variable resistance were placed on the back, each secured by adhesive tape, to act as a power source and fine-tuning the current, respectively. The rats were allowed to recover overnight in individual cages. In the experiment, each electrode was connected to the electric cell and a direct current $(200 \mu \mathrm{A})$ was applied continuously for $4 \mathrm{~h}$. Test compound or its vehicle was intravenously infused at the dose indicated during electrical stimulation. After current application was stopped, the rats were anesthetized again, and the thrombus formed was removed and its wet weight was measured with an electronic balance. Results are expressed as the means \pm S.E. of 10 rats.

\section{References}

1) Schneiderman J., Loskutoff D. J., Trends Cardiovasc. Med., 1, 99102 (1991).

2) Nilsson I. M., Ljungner H., Tengborn L., Br. J. Med., 290, 1453-1456 (1985).

3) Wiman B., Ljungberg S., Chmielewska J., Urden G., Blomback M., Johnsson H., J. Lab. Clin. Med., 105, 265-270 (1985).

4) Juhan-Vague I., Valadier J., Alessi M.C., Aillaud M. F., Ansaldi J., Philip-Joet C., Holvet J., Serradimigni A., Collen D., Thromb. Haemost., 57, 67-72 (1987).

5) Wieczorek I., Ludlam C. A., Fox K. A. A., Am. J. Cardiol., 74, 424429 (1994).

6) Krishnamurti C., Barr C. F., Hassett M. A., Young G. D., Alving B. M., Blood, 69, 798-803 (1987).

7) Reilly C. F., Fujita T., Mayer E. F., Siefried M. E., Arteriosccler. Thromb., 11, 1276-1286 (1991).

8) Carmeliet P., Stassen J. M., Schoonjans L., Ream B., Van den Oord J. J., De Mol M., Mulligan R. C., Collen D., J. Clin. Invest., 92, 27562760 (1993).

9) Levi M., Biemond B. J., Van Zonnenveld A. J., Ten Cate J. W., Pannekoek H., Circulation, 85, 305-312 (1992).
10) Biemond B. J., Levi M., Coronel R., Janse M. J., Ten Cate J. W., Pannekoek H., Circulation, 91, 1175-1181 (1995).

11) Folkes A., Roe M. B., Sohal S., Golec J., Faint R., Brooks T., Charlton P., Bioorg. Med. Chem. Lett., 11, 2589-2592 (2001).

12) Folkes A., Brown S. D., Canne L. E., Chan J., Engelhardt E., Epshteyn S., Faint R., Golec J., Hanel A., Kearney E., Leahy J. W., Mac M., Matthews D., Prisbylla M. P., Sanderson J., Simon R. J., Tesfai Z., Vicker N., Wang S., Webb R. R., Charlton P., Bioorg. Med. Chem. Lett., 12, 1063-1066 (2002).

13) Wang S., Golec J., Miller W., Milutinovic S., Folkes A., Williams S., Brooks T., Hardman K., Charlton P., Wren S., Spencer J., Bioorg. Med. Chem. Lett., 12, 2367-2370 (2002).

14) De Nanteuil G., Lila-Ambroise C., Rupin A., Vallez M. O., Verbeuren T. J., Bioorg. Med. Chem. Lett., 13, 1705-1708 (2003).

15) Ye B., Bauer S., Buckman B. O., Ghannam A., Griedel B. D., Khim S. K., Lee W., Sacchi K. L., Shaw K. J., Liang A., Wu Q., Zhao Z., Bioorg. Med. Chem. Lett., 13, 3361-3365 (2003).

16) Ye B., Chou Y. L., Karanjawala R., Lee W., Lu S. F., Shaw K. J., Jones S., Lentz D., Liang A., Tseng J. L., Wu Q., Zhao Z., Bioorg. Med. Chem. Lett., 14, 761-765 (2004).

17) Gopalsamy A., Kincaid S. L., Ellingboe J. W., Groeling T. M., Antrilli T. M., Krishnamurthy G., Aulabaugh A., Friedrichs G. S., Crandall D. L., Bioorg. Med. Chem. Lett., 14, 3477-3480 (2004).

18) Hu B., Jetter J. W., Wrobel J. E., Antrilli T. M., Bauer J. S., Di L., Polakowski S., Jain U., Crandall D. L., Bioorg. Med. Chem. Lett., 15, $3514-3518$ (2005)

19) Elokdah H., Abou-Gharbia M., Hennan J. K., McFarlane G., Mugford C. P., Krishnamurthy G., Crandall D. L., J. Med. Chem., 47, 34913494 (2004).

20) Miyazaki H., Ogiku T., Sai H., Ohmizu H., Murakami J., Ohtani A., Bioorg. Med. Chem. Lett., 18, 6419-6422 (2008).

21) Wakharkar R. D., Deshpande V. H., Landge A. B., Upadhye B. K., Synthetic Communications, 17, 1513-1517 (1987).

22) Brower J. O., Lightner D. A., McDonagh A. F., Tetrahedron, 57, 7813-7827 (2001).

23) Babu P. R., Balasubramanian T. R., Indian J. Chem., 26B, 63 (1987).

24) Dorward K. M., Guthrie N. I., Pelkey E. T., Synthesis, 15, 2317-2322 (2007).

25) Keijer J., Linders M., Zonneveid A. J., Ehrich H. J., Bore J. P., Blood, 78, 401-409, (1991).

26) Narita H., Kaburaki M., Doi H., Yasoshima A., Murata S., Jpn. J. Pharmacol., 68, 397-404 (1995). 